\title{
THE INSWINGING THEORY
}

\author{
POR
}

AITOR IRIARTE

Dedicated to the memory of John Anstee

\begin{abstract}
RESUMEN
Did bow-arms in ancient Greco-Roman palintone shooting machines swing by the outside or by the inside of the frame?. Unfortunately, and in spite of the widespread belief, this question has no definite answer yet. Available archaeological, textual and pictorial evidence has been assembled together and discussed in this paper, so that readers will be able to draw their own conclusions.

¿Se movían los brazos de arco en las piezas artilleras palíntonas del período Greco-Romano por el exterior o por el interior del bastidor? Lamentablemente, y a pesar de la creencia general, todavía no disponemos de una respuesta clara para esa pregunta. En este artículo ha sido reunida y comentada toda la información arqueológica, literaria e iconográfica a mi alcance, de modo que quien lo lea pueda sacar sus propias conclusiones al respecto.
\end{abstract}

\section{KEY WORDS - PALABRAS CLAVE}

Artillery. Greco-Roman. Palintones. Bow-arms. Outswinging. Inswinging.

Artillería. Greco-Romana. Palíntonos. Brazos de arco. Externos. Internos.

\section{INTRODUCTION}

Surely one of the most vivid areas of discussion on the study of Greco-Roman artillery today is that concerning the position of the bow-arms in the palintones. Well, maybe to call it 'vivid' is not fairly accurate, because scholars defending the 'official' theory, instead of descending to the battlefield of open-minded scientific discussion, have comfortably barricaded themselves behind the shield of 'oh, twaddle!'. I was not very far from that position just a few years ago, but now I believe that things are not so settled as many people may think, and time has come to put together all available evidence about the matter, with the hope of sparkling at least a serious discussion on it.

The subject is no novelty. During the second half of nineteenth century, French scholars attempted the first 'archaeological' reconstructions of ancient torsion artillery. Some of them ${ }^{1}$ already felt that, in the stone-shooting palintone engines, the bow arms swung within the frame and, therefore, projected forwards when they were at rest (Fig. 1). Nobody doubted, of course, that the arrow-shooting euthytone machines had sideways projecting arms, swinging by the outside of the frame.

\footnotetext{
1 Prou (1877), 22-23, 63-72, 80-88, 111-114.
} 


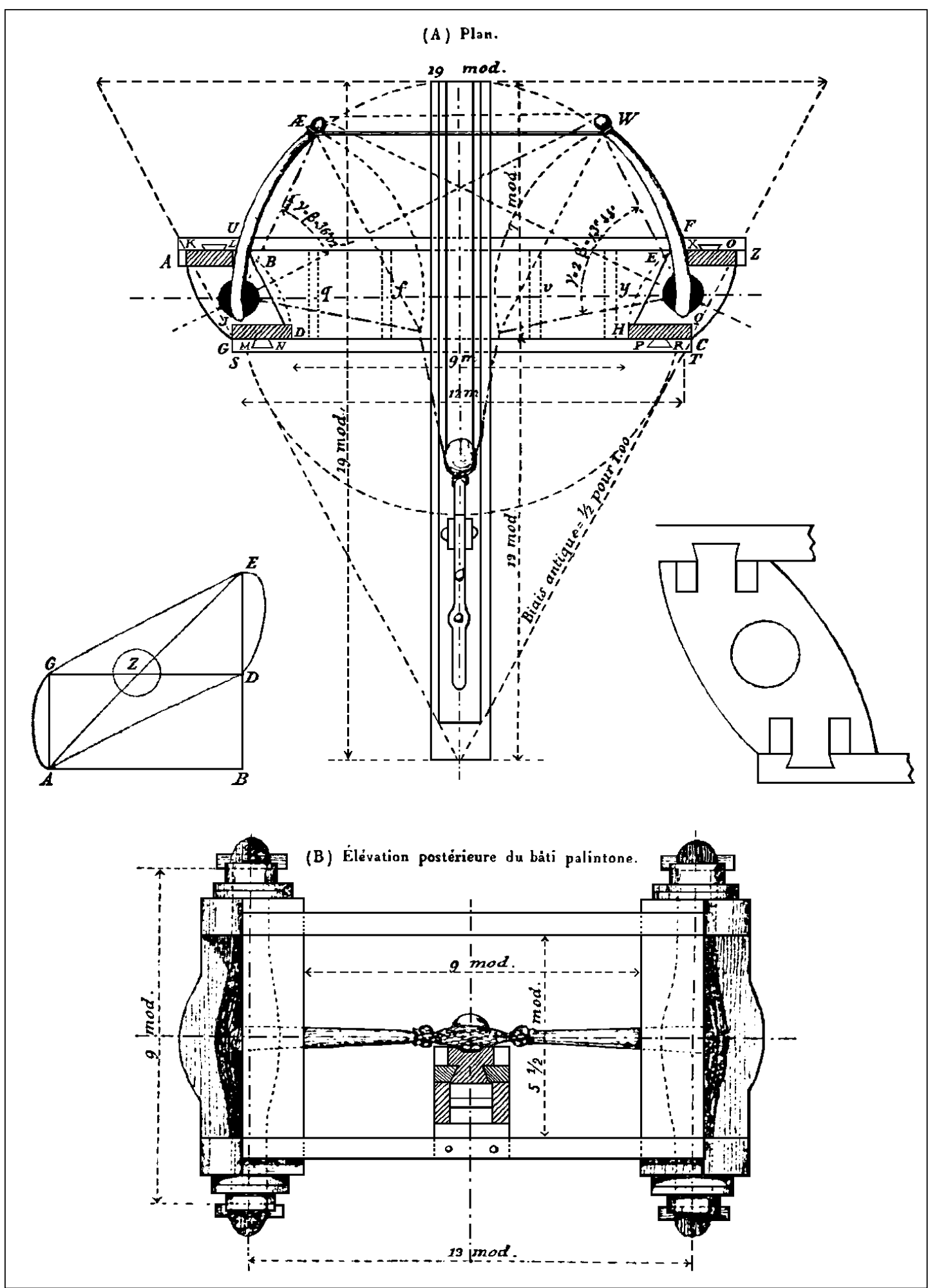

Fig. 1. Victor Prou's reconstruction of the palintonon. 
Since, at the beginning of the past century, the German military Erwin Schramm ${ }^{2}$ arrived to the conclusion that palintone machines had outwards swinging arms, the French proposals were regarded as beginners' nonsense ${ }^{3}$ and, subsequently, were cast into oblivion.

\section{THE HATRA BALLISTA}

So were things until the first archaeological remains of a stone-shooting ballista were discovered at Hatra (Iraq) in $1972^{4}$. Mainly, the bronze sheeting once protecting the long ago vanished wooden frame, alongside with washers and counter-plates, were recovered. Enough to reconstruct the frame with some confidence and enough to rock the until then commonly accepted ideas on palintones.

The Hatra frame exhibits some extremely puzzling features (Fig. 2, 3). First, it was built in 'one piece' out of several beams mortised together, like those belonging to euthytone arrow-shooters, instead of assembling several sub-components, as it was the norm in palintones. Second, the frame is unusually wide for its height, 2.86 times wider than higher 5 . Third, the cut out recesses for receiving the arms are placed in the inner faces of the sidestanchions, instead of in the back faces, as it is the norm in arrow-shooters and was thought to be in stone-shooters, too.

I suppose that everybody knows what those cut out recesses were intended for, but I think that it will not be completely superfluous to remember here what Heron says about them and about the relation arm-stanchions, in general:

'Of the vertical walls, the one against which the arm recoils is called the side-stanchion; the other, against which the heel of the arm rests, is the counter-stanchion. The side-stanchion is made as follows. One must take a board of tough wood and square it off, in the middle of the side make a semicircular recess in its thickness (to give the arms still greater room to recoil and to separate them further), which can take the thickness of the arm. The arm recoils into this. On the other side, directly opposite the recess and equal to it, a convex bulge is made, so that the round protuberance may compensate for the weakness in the wood caused by the excision... The counter-stanchion must be made equal to this... But it has no convex or concave roundings... But the counter-stanchion, against which the arm presses and comes to rest, does have a pad at one point to meet the heel of the arm; this is called the heel-pad' ${ }^{6}$

Well, it is clear that the purpose of the recess in the side-stanchion is to receive the arm in its recoil, when it returns to the rest position, and to allow it more room for its movement, so it can use a bigger part of the energy stored in the spring. On the other hand, the arm's heel must end its travel against the counter-stanchion. The counter-stanchions in the Hatra machine have fully vanished, but the side-stanchions and their recesses are perfectly traceable from their bronze platting. Hence, if the arms must recoil against the recesses, the only way they could do it in the Hatra ballista was just swinging by the inner side of the frame; there was no problem as the Hatra frame is wide enough as to leave room for the movement of two arms of the standard palintone length, plus a stone shot and some more extra space.

\footnotetext{
2 SCHRAMM (1918), 54-57, 69-70, Taf. 4.

3 SCHRAMM (1918), 12-13.

4 BAATZ, (1978), 3-9. There are no clear positive proofs about the kind of missiles it shot. Anyway, the sheer dimensions of the frame $-2.40 \times 0.84 \mathrm{~m}$ - and its spring diameter $-16 \mathrm{~cm}$ - appear enough to classify the Hatra machine as a stone-thrower.

5 The only other complete, over three centuries earlier, frame-sheathing, that of the Caminreal arrow-shooter, is just 1.17 times wider than higher, even though this capitulum is slightly 'low' or catatonic, if we are to believe Philon's or Vitruvius' specifications. VICENTE et alii (1997), 179-181.

${ }^{6}$ Heron, Bel. W. 91-93. All the translations, unless otherwise stated, are by Eric W. Marsden. MARSDEN (1971).
} 


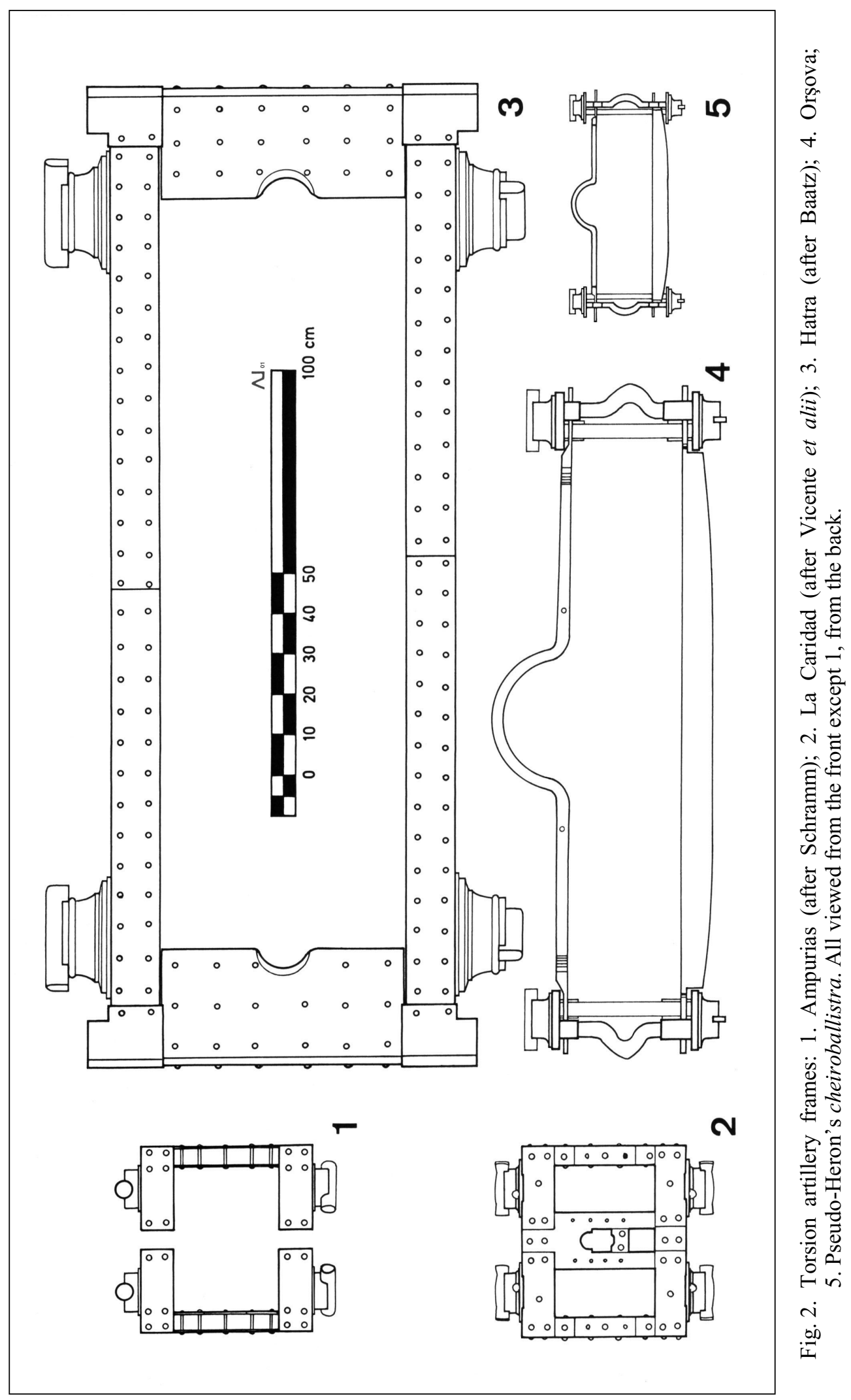


Counter-stanchions were mechanically needed in the Hatra ballista, not only to stop the arms' heels but also to support the enormous compressive force transmitted by the springs to both counter-plates; the question of their width is open to debate ${ }^{7}$.

Oh my God! I have said that the Hatra ballista was an inswinger! This is not really a new idea, the late — and sorely missed - John Anstee had already pointed it out ${ }^{8}$, but it implies delving deep into the sea of scientific 'heresy', far deeper than some scholars are ready to admit. It is rather incongruous, for example, to deprecate, on one side, those modern catapult reconstructions 'made with little attention to the words of Greek and Roman engineers or to the ever increasing archaeological evidence' ${ }^{\prime}$ and, on the other side, dismiss the 'totally erroneous premise that the Hatra stone-thrower had such (inwards swinging) arms' ${ }^{10}$, when both the Hatra remains and Heron's Belopoeika point strongly in that direction.

Anyway, we can also read that 'The Hatra machine is readily restored, advantageously, with standard outswinging arms' 11 but, when is it possible to understand that a machine functions properly? Anybody involved with real working catapults knows that any machine with springs thick enough, and which can withstand to be cocked and shot without crumbling away or bursting apart, will reach easily a range of fifty, sixty meters; notwithstanding, it will by no means be termed as successful. Only if a catapult can match or even surpass its peers' output will it be successful. To a given spring diameter ${ }^{12}$, the amount of energy transmitted from the springs to the arms will mark the difference, and that amount is measured in the degrees of arc travelled by the arms. Let us see, thus, how viable would it be the Hatra ballista if equipped with outswinging arms. The bronze corner-fittings make it clear that vertical posts did also exist at the back outer sides of the frame, this is no surprise and they are distinctly traced on Baatz's drawings of the frame and tentative reconstruction ${ }^{13}$. Such stanchions, even reduced to the minimum width ${ }^{14}$, would have greatly limited the arc travelled by the arms, in case they had been positioned in the usual outswinging way. Speaking in degrees, this arc could never have exceeded of $35^{\circ 15}$ (Fig. 3a), which would have been clearly unsatisfactory, if we take into account that $45-50^{\circ}$ have been estimated already for standard Hellenistic stone-throwers ${ }^{16}$ and even $47.5^{\circ}$ for the advanced Vitruvian arrowshooter ${ }^{17}$. With an inswinging configuration, the arms of the Hatra ballista could have travelled across a minimum of $103^{\circ 18}$ (Fig. 3b). Moreover, if it would have been an outswinger,

7 The rebates on the bronze corner-fittings indicate that the 'hole-carrier' did not ran flush with the side-stanchion. If we suppose that the 'hole-carrier' extended symmetrically towards the inner side of the frame, then the width of the counter-stanchion would be roughly the same than that of the side-stanchion minus the recess for the arm. Thus, we could infer that the designer of the Hatra ballista reinforced the whole length of side-stanchions, instead of just leaving bulges protruding from their middle, as it was usual. The Ampurias catapult too lacked those bulges, but its designer did not consider necessary to reinforce the side-stanchions.

8 ANSTEE (1998), 131-132. Of course, he is not the only one of such opinion, as far as I know.

9 WILKINS \& MORGAN (2000), 90.

10 WILKINS \& MORGAN (2000), 100.

11 WiLKINS \& MORGAN (2000), 100.

12 With their $16 \mathrm{~cm}$ of diameter, the Hatra springs are the thickest ones so far archaeologically attested. Such big an expensive machine should be intended not only to impress the enemies but to hurl missiles at them effectively.

13 BAATZ (1978), fig. 2 and 7.

14 That of the corner-fitting.

15 Of course, some extra degrees could be won resorting to expedients like employing curved arms or cutting notches into the 'back-stanchions'. Well, the first alternative is not unviable, however, no sources refer to such characteristic on palintones; the second alternative, notwithstanding, would become ridiculous, since it would entail constructing a catapult with four side-stanchions.

16 MARSDEN (1969), 22, fig. 12.

17 MARSDEN (1971), 230, fig. 12.

18 Some extra degrees could be won also in this case by carving notches into the counter-stanchions. Nevertheless, the sources tell distinctly that counter-stanchions were straight and were provided with a pad. The surviving front plating from the Cremona and Caminreal catapults - both euthytone scorpions - should have ineludiblely reflected such indentations and they do not. Therefore, I have renounced to that advantage in my graphic reconstruction. 
the arms' heels would not have been stopped at all by the heel-pads on the counter-stanchions, with the result that either the - comparatively weak and unnotched- back-stanchion or the bowstring itself would have to absorb the whole shock of the recoil, which would surely prove too much for them at short or medium term. In conclusion, the Hatra machine would be of - to say the least - dubious efficiency as an outswinger and it would perform more logically as an inswinger.



Fig. 3. The Hatra ballista configured as an inswinger (left) and as an outswinger (right).

\section{THE ROMAN METALLIC-FRAMED BALLISTAE}

The city of Hatra was stormed and destroyed by the Sassanid Persians in the middle of the third century AD and, therefore, the ballista reached the earth no later than this date. Was this machine just an oddity or was it a standard one? Well, the frame's type of construction looks really strange ${ }^{19}$, but not perhaps in Hatra, where a pair of corner-fittings belonging to

19 Anyway, it is important to remember that, apart from the descriptions in the treatises, which are furthermore several centuries older than the Hatra ballista, no other component belonging to a stone-thrower has up till now been attested in the archaeological record. 
another, smaller, catapult have been found ${ }^{20}$. Nevertheless, in my opinion, this way of positioning the recesses for the arms could be a common feature to all Roman advanced, metallic-framed artillery. This idea is far from being universally accepted, and it is not a matter of fact, like the Hatra frame is, but I think that it is the best and simplest way of reconciling the diverse technical features exhibited by the extant archaeological remains, as I have reasoned in the first part of my paper on the cheiroballistra ${ }^{21}$ (Fig. 2, 4 \& 5).

As it becomes quickly clear, in that first theoretical approach to the matter, I provided the machines with outwards swinging arms. I did it, regardless of Heron's clear instructions on the relationship arm / counter-stanchion / side-stanchion, because I deemed then inswinging as an unsuitable and improbable choice. Nevertheless, alterations to machines usually provoke malfunctions and, therefore, during the trials with my cheiroballistra, I found out that, even if in such configuration the arms had room enough to make profit of the energy stored in the springs, the lack of an operative side-stanchion/counter-stanchion system made the arms unstable in the recoil. In other words, there was nothing to stop the arms when they returned to their resting position, and the slightest unbalance between both springs' strength caused one arm to continue its movement forwards until it stopped against the bulge in the kambestrion, while the other arm was dragged inwards by the former one's pull, via the bowstring. The arms showed the same nasty tendency when being at rest. It is not very complicated to correct by hand the arms' position in a small and not very powerful catapult as the cheiroballistra is but it would be practically impossible in standard medium ballistae, like those of Orşova, Lyon or Sala ${ }^{22}$, not to mention in even bigger ones. Summing up, it is difficult to envisage why the Roman army should have radically changed the structure of its arrow-shooters if only small counterparts like a modest increase in power or an enlarged field of vision were at play, and even more difficult to understand why did they adopt those outswingers as its standard artillery when they were unreliable and potentially dangerous machines. In case we accepted that, in Roman metallic-framed ballistae, the arms swung by the inside, the picture would fit more neatly, i.e., the wide frames would allow for the inner movement of the arms and the side- and counter-stanchions would perform correctly their duties $^{23}$ (Fig. 4).

It is usual to hear or read that the inswinging configuration is only good on paper, but it would offer no significant advantage, if not hindrance, in the practice ${ }^{24}$. The arguments adduced to prove such statement perhaps could be valid to demonstrate that Achilles will never catch up with the tortoise or the like but, as I have already written elsewhere ${ }^{25}$, only practical tests on catapults of the same calibre will show if the inswinging configuration really works.

20 BAATZ (1978), 7.

21 IRIARTE (2000), 60-63, fig. 10 \& 14.

22 Orşova, BAATZ (1978), 9-14; Lyon, BAATZ \& Feugere (1981); Sala, Boube-Picot (1994), 188-191. Had the Sala catapult belonged to an outswinger, its exceedingly wide stanchions would have restricted the traveling of the arm to only $38^{\circ}$, while with inswinging configuration it would have reached about $66^{\circ}$. Not a great performance, anyway, but enough to justify at least that the Sala ballista was a serviceable weapon, as the traces of use on the kambestrion prove beyond doubt. IRIARTE (2000), 63, 66 fig. 16, 2 .

${ }^{23}$ It is really curious to see how diverse solutions have been adopted for the positioning of the kambestria by some scholars, but never the one here proposed, no matter if sometimes the Hatra frame was illustrated side by side on the same paper. BAATZ (1978), 13 fig. 11; BAATZ \& FeUgere (1981), 208 fig. 12; BAATZ (1988), 63 fig. 7; BOUBE-PICCOT (1994), 194, pl. Z3; BARKER (1999), 21 fig. 10. Alan Wilkins has gone beyond them all conjuring from his imagination complex and unattested systems of linking rings, with the only goal of rotating the field-frames enough as to return the sidestanchions more or less to the 'orthodox' position -WILKINS (1995), 34-38- . He has also recently written that the cheiroballistra cannot be an inswinger because - WILKINS \& MORGAN (2000), 100 - 'to avoid clashing, the arms have to be shortened by about 25\%', well that would be really a fair solution, because he had previously - extremely and undulylengthened his cheiroballistra's arms. See WILKINS (1995), 32-34 and IRIARTE (2000), 59 for commentary.

24 WILKINS \& MORGAN (2000), 100.

25 IRIARTE (2000), 63. 
I have carried out such tests on my reconstructed cheiroballistra and, therefore, I can positively affirm that, in my machine, the inswinging configuration represents an improvement in range of about $40 \%$ with respect to the outswinging one ${ }^{26}$.

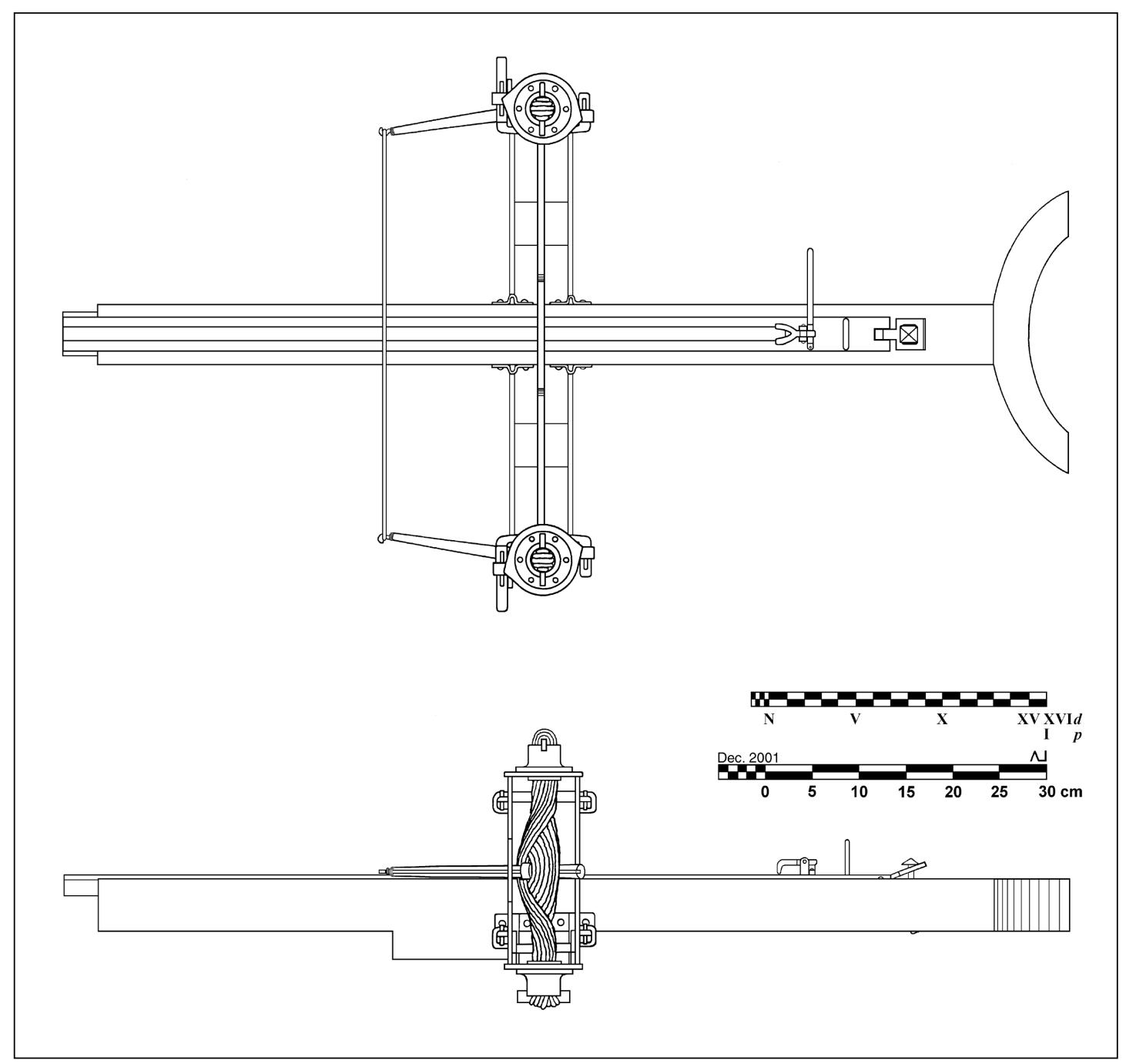

Fig. 4. Pseudo-Heron's cheiroballistra configured as an inswinger.

There are some descriptions of Late Roman metallic-framed ballistae by contemporary writers. Unfortunately, all of them are rather jumbled and very untechnical texts, of little help to solve our problems, if they do not increase them ${ }^{27}$. Only Ammianus' description is of some limited use for the purpose of this paper, it says ${ }^{28}$ : 'An iron strut is fixed firmly between two little posts, it is sizeable and stretches out like a rather large ruler. From a well-finished

26 The tests, when completed will, hopefully, be the subject of the second part of my paper on the Cheiroballistra, titled 'Pseudo-Heron's cheiroballistra, a(nother) reconstruction: II.-Practice'.

27 They are collected together and carefully surveyed in MARSDEN (1971), 234-248.

28 Ammianus, Res Gestae XXIII, 4, 2. 
joint in this, which a smoothed portion in the middle forms, a rectangular beam emerges rather a long way, fitted with a straight narrow-channelled groove, and bound in the complex cordage of twisted sinews.' Marsden rightly identified the 'rectangular beam' with the case ${ }^{29}$. Well, the case only protrudes noticeably forwards in an inswinger. Notwithstanding, Ammianus is ambiguous as to whether he is looking at the machine from the front or from the rear, and his mention to the windlass that follows perhaps would hint at the second choice.

The metallic-framed ballistae are attested for the first time in the relieves on Trajan's Column. This is, sadly, their only occurrence on sculpture. The machines depicted appear to be medium sized static or mobile ballistae (maybe carroballistae, or maybe not). Their seeming lack of arms has been used as an evidence of their inswinging configuration ${ }^{30}$. In my opinion, the machines on the Column were effectively inswingers, but the too many inconsistencies in the depictions advise to take their details with some caution. Anyway, two of the ballistae exhibit bulges protruding laterally from the cylinders encasing or representing the springs (Fig. 5); I think that they depict the outer curves on the kambestria's sidestanchions ${ }^{31}$. Therefore, the recesses for the arms would be in the same position than in the Hatra machine and this fact could be used as more positive evidence in favour of the machines' inswinging condition than the circumstantial one provided by the apparent absence of the arms. Additionally, four of the machines depicted ${ }^{32}$ exhibit longitudinally grooved stocks, protruding ostensibly forwards from the frame; of course, it could be always alleged that the beams represent only the sliders.

It was Schramm the first scholar who supposed that the ballistae featured on Trajan's column should have had iron frames. He thought that the adoption of such departure from the traditional way was due mainly to the desire of saving the portions of expensive rope which ran inside the old, one hole thick, wooden hole-carriers ${ }^{33}$. The recovery of several field-frames has proved that, effectively, in the metallic-framed machines, the springs were shorter than in their wooden-framed forerunners. Philon says that, in wooden palintones, 'the complete height of the half-spring when totalled up is 9 diameters, not counting the levers ${ }^{\prime 34}$. Only the Lyon kambestrion retains its original washers but, restoring approximately the missing ones to the other field-frames, the figures are 7.65 for Sala, 7.54 for Orşova, 5.67 for Lyon and the extreme 4 for Gornea, all of them very far from the Philonian ideal. Notwithstanding, Schramm's idea, seductive as it is, is not backed at all by the wooden-framed Hatra find, where the length of the springs, from washer to washer, is only 6.65 times the spring diameter. Hence, if the reduction in height of the springs had nothing to do with construction material, the motive for the change was not the saving of spring-cord and remains a mystery. Perhaps the engineers responsible for the design of Roman advanced artillery were just seeking to develop more power on impact, even if such characteristic would go in detriment of range ${ }^{35}$.

\footnotetext{
29 MARSDEN (1971), 239 n. 4.

30 PROU (1877), 113; ANSTEE (1998), 133.

31 Casts 105, 163-164. Schramm -SCHRAMM (1918), 32, 34- already noticed them. IRIARTE (2000), 61-62 fig. 11 \& 12

32 Casts $165-166$ and 169.

33 SCHRAMM (1918), 31-34.

34 Philon, Bel. 53.

35 MARSDEN (1971), 160-161, n. 22.
} 

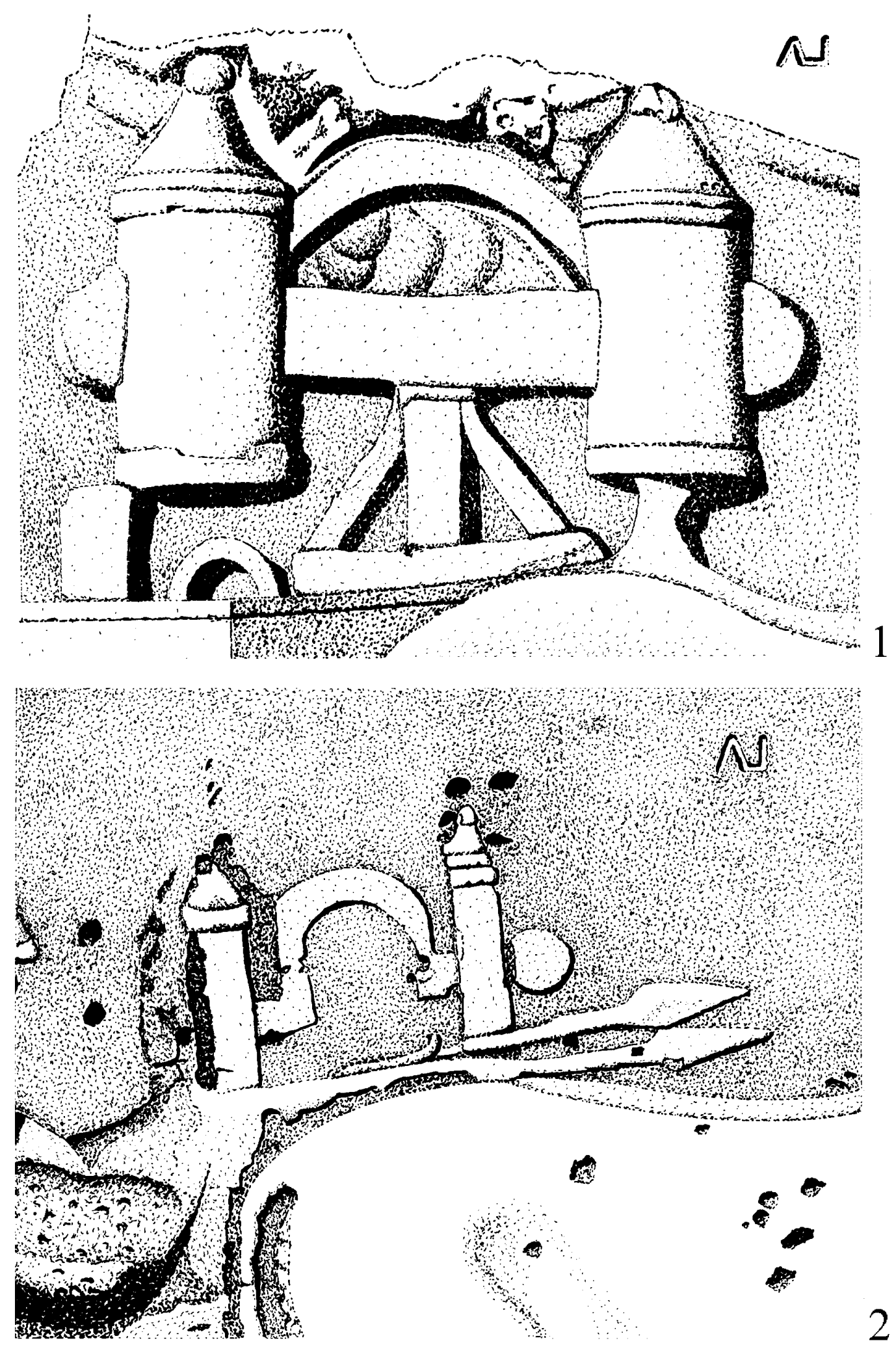

Fig. 5. Ballistae on Trajan's Column: 1. Scene XLVI, Casts 163-164; 2. Scene XL, Cast 105. 


\section{THE WOODEN PALINTONES}

Anyone familiar with the hemitonia or half-springs in the Hellenistic or Early Roman wooden palintones (Fig. 6), when confronted with metallic field-frames, will not be able to avoid a strong feeling of déjà vu. Particularly striking is the massive Sala kambestrion (Fig. 7), which can hardly be defined as anything but a half-spring cast in bronze. The rest of archaeological field-frames repeat, though in a more stylised way, the same idea: a pair of 'diamond' shaped hole-carriers joined by two stanchions, one of them having a bulge in the middle. The Orşova field-frame (Fig. 8) is a representative example of them.

If the kambestria in the Roman advanced arrow-shooting ballistae were seemingly just metallic versions of their wooden forerunners, the hemitonia, then conceivably it would not be too far fetched to suppose that also the way they were positioned in low wide frames was aping that of their wooden predecessors. In that sense, Prou's reconstructive drawing of the palintonon $^{36}$ (Fig. 1), made one hundred years before the Hatra remains were recovered, results more than strikingly foreshadowing. Possibly the main contribution to artillery by Roman engineers was to replicate in iron what was formerly wooden, because palintones were employed since Hellenistic times to shoot arrows too, as Heron ${ }^{37}$ and Athenaeus Mechani$\operatorname{cus}^{38}$ let us know.

In comparison with later Roman developments, there is plenty of written information concerning wooden two-armed stone-shooters. So much that it has become a 'matter of fact' to think that the ancient treatise writers - i.e. Philon, Heron and Vitruvius - put in their works nearly all, if not all, the information necessary to reconstruct the wooden-framed palintones; moreover, in case that some isolated detail had remained obscure, the work of experts like Schramm or Marsden would have already clarified it beyond doubt. On my turn, I think that the too many unclear points in the descriptions on the treatises leave open more than one way of interpretation, furthermore when we do not possess even the tiniest scrap of metal which we can claim that once belonged to a palintonon and which could help us to solve at least some of those troublesome spots ${ }^{39}$.

Philon and, chiefly, Heron, in their treatise's sections devoted to wooden stone-shooters, describe quite painstakingly the construction of the half-spring ${ }^{40}$, but they are not so concerned with that of the rest of the frame.

Heron's description is by far the most accurate, he starts: 'Imagine the two half-springs ready strung as described, and resting on boards (beams), and a little further apart from one another than twice the length of one arm' ${ }^{41}$ Heron seems to be distinctly stating that the frames were low and wide. Moreover, when he later writes that: 'Euthytones are in all other respects the same as the palintones; but the two half-springs are combined in one frame, and are the breadth of the slider apart'. ${ }^{42}$, he is perhaps emphasizing that one of the main differences between both kinds of machines is that, in euthytones, the half-springs are just the 'breadth of the slider' apart, while, in palintones, they are slightly more than 'twice the length of one arm' apart; i.e. the palintone frames are wide and low and the euthytone ones are quite narrower.

36 Prou (1877), 69, Fig. 9.

37 'Palintones are called stone-throwers by some because they discharge stones; but they shoot arrows, or stones, or both.' Heron, Bel. W. 74.

38 'His (Agesistratus') four-cubit, a palintone, shot (a bolt) four stades', Peri Mech. W. 8.

${ }^{39}$ Like it is the case with the euthytones.

40 Philon, Bel. 52-53. Heron, Bel. W. 91-99; part of the description is reproduced on the section devoted to 'The Hatra Ballista' in this paper.

${ }^{41}$ Heron, Bel. W. 99. Marsden tends to translate diversely as 'board', 'beam' or 'joist' what in the Greek manuscripts is designed simply as ' $\kappa \alpha \nu \omega v^{\prime}$ '. He did it surely with the excellent intention of clarifying the meaning of the somewhat obscure text but, what he in fact sometimes accomplished was to affect misguiding connotations to the words.

42 Heron, Bel. W. 104. 


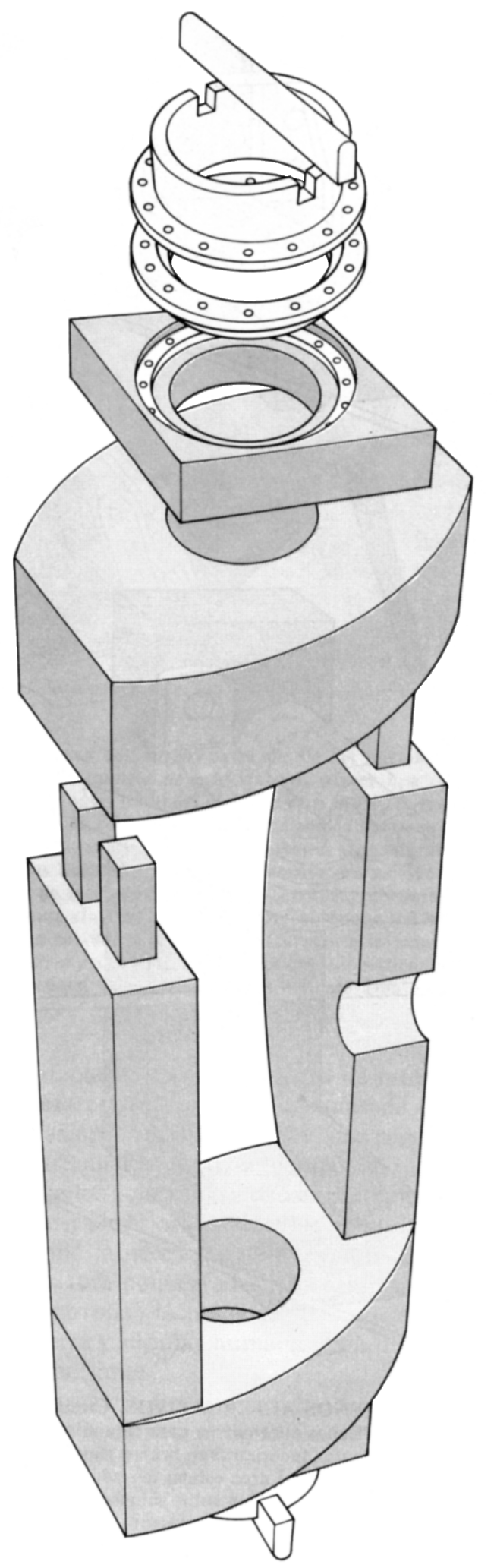

Fig. 6. Palintone's half-spring (after Soedel \& Foley). 

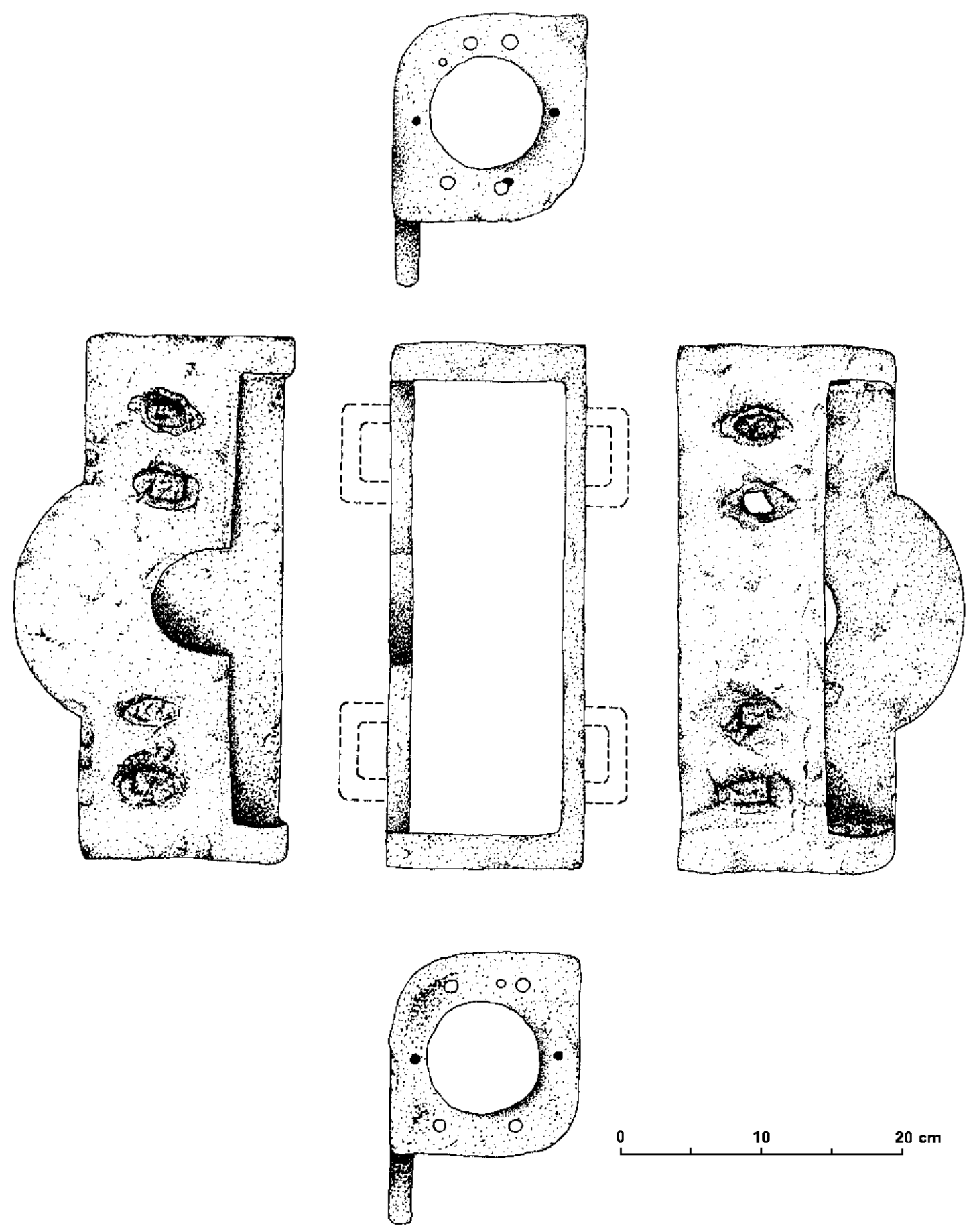

Fig. 7. The Sala kambestrion (after Boube-Piccot). 
Heron gives us the only - albeit a little faint - clue on how the half-springs were connected to the beams: 'Imagine, too, that the lower hole-carriers of the half-springs $A B \Gamma \Delta$, EZH $\Theta$ have tenons projecting, and are joined by boards (beams) $\Sigma T Y \Phi$ in which the tenons fit. You must plan the same system on top also'43. Well, that arrangement would work better if straight beams were attached to tenons protruding from the hole-carriers' straight sides, like it would be the case in an inswinger. Of course, this argument is not conclusive at all again, but it finds support on the identical position of the tenons' counterparts, the pittaria, on the metallic kambestria. They stem from the bars/stanchions instead of from the 'rings'/hole-carriers, but we must remember that the 'rings' are now far thinner than the $1 \mathrm{D}$ thick wooden hole-carriers were.

Heron continues with the description of the frame: 'But the lower boards (beams) are further fitted with several cross-pieces like $X \Phi \Psi \Omega$; on these cross-pieces is placed a plank filling the whole space between the boards. The framework, comprising beams, cross-pieces and planks is called the table'. This description of the 'table'. ( $\tau \rho \alpha \dot{\alpha} \varepsilon \zeta \alpha$ ) does not fit exactly with the reconstructions by Schramm or Marsden ${ }^{44}$, which portrait it as a longitudinal feature, protruding backwards from the frame and somewhat autonomous with respect to it. Heron's description talks of cross-pieces linking both lower beams of the frame together and having on them a plank; all of them forming properly the 'table', which, hence, would not be an independent element. The table's function seems to be more related with rigidifying the lower part of the frame to receive the stresses transmitted by the ladder than with connecting the latter to the frame itself. Unfortunately, Heron says nothing about the way of linking the ladder to the table in the frame, this omission is a serious obstacle to any attempted reconstruction of the palintonon, as Marsden already noticed ${ }^{45}$. Another interesting characteristic of the description is that it does not mention the actual number of cross-pieces, designed with the letters $X \Phi \Psi \Omega$. Heron uses to name longitudinal elements with two letters ${ }^{46}$, but not always, however. An striking parallel on the same Belopoeika are the four cross-pieces belonging to the 'stretcher', $E, Z, H, \Theta$, each one of them designed with only one letter ${ }^{47}$. Furthermore, when Heron writes later in the description ${ }^{48}$ that: 'The case, in which are the slider, the block and the claw, is called the case in euthytones, but ladder in palintones, since it is wider and it is joined by several cross-pieces like the table', he gives the impression of being alluding to a longish structure possessing more than two cross-pieces ${ }^{49}$. At once, the 'ladder' of the cheiroballistra, performing the same function and comprising three 'cross-pieces', comes to mind ${ }^{50}$.

To finish with Heron, it is noticeable his interest in what could be considered an obvious matter, that is, the direction in which both arms move. Heron is at pains to explain that: 'Thus, when the half-springs are strung and the arm recoils outwards - the one in $А В \Gamma \Delta$

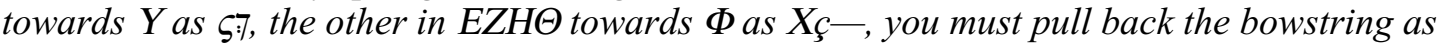
described, load the missile, and squeeze the trigger.' $Y$ and $\Phi$ are the tips of one of the lower connecting beams, i.e. the beam $Y \Phi$. This apparently straightforward instruction is, sadly, quite useless, because the diagram with the original sequence of identifying letters as arran-

43 Heron, Bel. W. 99

44 SChrAmm (1918), 56, Abb. 22. MARSDEn (1971), 55, Fig. 18; 56, Fig. 20b; 203, Fig. 11; Diagram 11 b.

45 MARSDEN (1971), 54-55, n. 32.

46 Therefore, it would be fair to suppose that there were only two cross-pieces, i.e. $X \Phi$ and $\Psi \Omega$, as Marsden does, MARSDEN (1971), 55, Fig. 18.

47 Bel. W. 107. The four elements are clearly designed on the corresponding diagram with only one letter each. M fol. 54, reproduced in WESCHER (1867), 109, fig. XXXV.

48 Heron, Bel. W. 100.

49 Prou reconstructed four, allotting one letter to each cross-piece. See Fig. 1 in this paper and PrOU (1877), 69, Fig. 9; 70.

50 For the 'ladder' in the cheiroballistra, see IRIARTE (2000), 57-59, Fig. 7.2. 


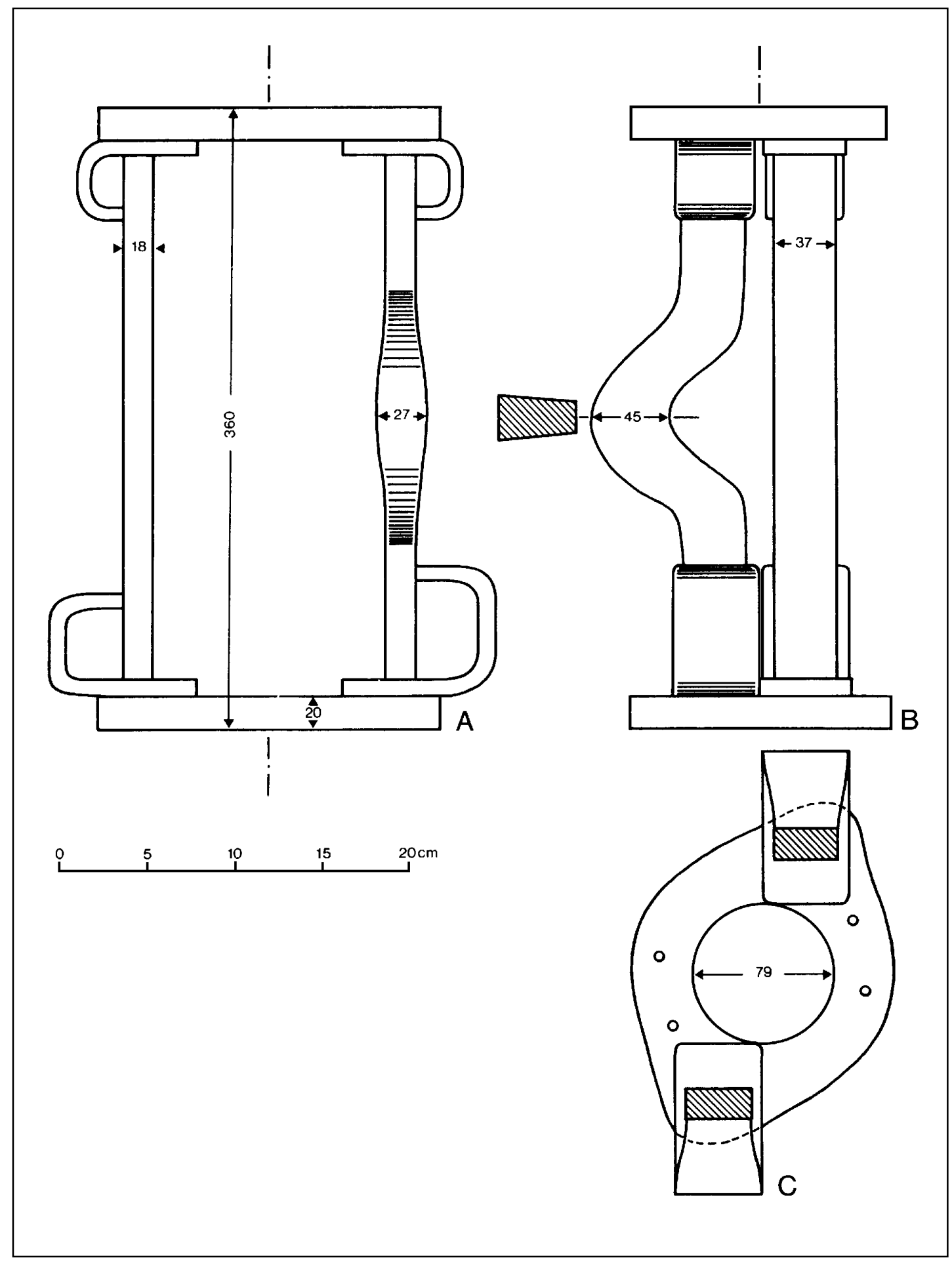

Fig. 8. The Orşova kambestrion (after Baatz). 
ged by Heron is lost ${ }^{51}$ and it depends totally on the modern scholar's wishes to reconstruct diagram and lettering pointing towards outswinging or inswinging 52 .

Philon says very little about the frame, just an uncomplete list of components and dimensions, after describing the half-spring, he follows: 'The length of the sling is two and onetenth times the length of one arm ${ }^{\prime 53}$. This short phrase has been employed by Marsden to assert that the frame of the palintonon described by Philon was of the squarish, "conventional' kind ${ }^{54}$. Notwithstanding, this length of sling could, in fact, fit equally a wide inswinger stone-shooter, with its half-springs set apart the distance stated by Heron. To make it clear, I have put, side by side, the plan of an outswinger palintone, as reconstructed by Marsden (Fig. 9a), with that of an schematic inswinger palintone (Fig. 9b). To my surprise, the 12.6 D long sling preconized by Philon was too short for the frame of the outswinger, the arms could have traveled about $16^{\circ}$ more and, which is more important, the task of stopping them would have to be performed by the sling itself and not by the counter-stanchions, as it should have been (Fig. 9a). I have employed the design of the hole-carriers supplied by Heron, because it is, in my opinion, the clearest one and, moreover, the only one preserving its original accompanying diagram. The lack of concrete dimensions can be solved by using that of the length given by Philon 55 , i.e., $23 / 4$ D (2.75 D). Heron's peritreton can be inserted in a square, being the width of the stanchions half of its length, $1.38 \mathrm{D}$. Notwithstanding, Philon's figure for the width of the side-stanchion ${ }^{56}, 17 / 12 \mathrm{D}(1.58 \mathrm{D})$ is bigger than that and the resulting hole-carrier would be rather oblong, which would allow for a longer sling ${ }^{57}$.

The rest of Philon's text concerning the frame is even more vague: 'The length of the table is $9 \mathrm{D}$. The plank on the table is strong enough if it has a thickness of $1 / 8$ D. Make the joists (upper frames) of the table with the width and thickness of the ladder. Make the length of the beams suitable for the half-springs; make their width $\%_{9} D$, their thickness ${ }^{4} / 9$ D. ' Well, the two first phrases are quite clear, but the following one is really puzzling: ' $\tau \grave{\alpha} \delta \grave{\varepsilon}$

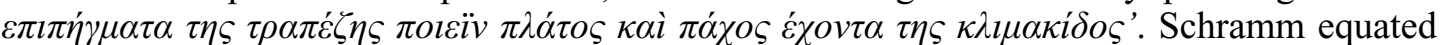
these 'ह́ $\pi i \pi \eta \gamma \mu \alpha \tau \alpha$ ' with the table's cross-pieces $\left(\delta l \alpha \pi \eta \gamma^{\prime} \mu \alpha \tau \alpha\right)$ mentioned by Heron ${ }^{58}$, but I deem it too far-fetched, because the noticeable gaps existing in Philon's description of the frame mar seriously any attempt to collate it, component by component, with Heron's one. Marsden's valiant translation of ' $\bar{\pi} \pi i \pi \eta \mu \alpha$ ' as 'joist' is not well supported by ethimology, while 'upper framework' or even 'upper planking' seems more adequate. Marsden, following Schramm, searched to identify the 'upper frames' as a pair of side beams which helped to conform the table like an autonomous element ${ }^{59}$, but that theory does not match at all

51 More details on the following section, 'Ancient Diagrams'.

52 See my Fig. 9a and 9b. After examining the surviving Belopoeika diagrams, no consistent way of ordering the letterings can be found which could support any of the two possible choices.

53 Philon, Bel. 54.

54 MARSDEN (1971), 54, n. 31. While supposing that there is a blunder or a misinterpretation in Heron's declaration about the distance between both half-springs in the frame.

${ }^{55}$ Heron, Bel. W. 94-96; diagram M fol. 50v, reproduced in Wescher (1867), 95, fig. XXIX. Philon, Bel. 53. Vitruvius description of the hole-carrier (De Arch. X, 11, 4.), besides being somewhat jumbled, presents a clearly corrupt figure for the length — VEL or VIII, depending on the manuscript — and, therefore, I have preferred not to rely on it.

56 Philon, Bel. 53.

57 Philon only mentions the dimensions of the side-stanchion and, of course, it can be always argued that those of the counter-stanchion are the same. Anyway, I would not like to leave this point without suggesting that the difference of $0.20 \mathrm{D}$ could be intended for the bulge and, therefore, Philon's width could be that of the undressed side-stanchion. Naturally, I remember that Vitruvius (De Arch. X, 11, 5.) says that the curvature of the excision (and, thus, the bulge) must be $0.5 \mathrm{D}$.

58 SCHRAMM (1918), 55

59 MARSDEN (1971), 161, n. 25: 'This is an abbreviated way of saying that the two joists of the table are to have a width and a thickness equal to those of the ladder's side-poles, measurements for which are given a sentence or two later. Thus, each joist will be $9 \mathrm{D}$ long (equal, of course, to the length of the table), $1 / 4 \mathrm{D}$ wide, and $1 \mathrm{D}$ high.' 
Heron's description of the table like an integral part of the frame, comprising the lower pair of beams linking both half-springs, several cross-pieces and an upper plank. I shall not dare to say that I have a better explanation for the table, but it will not be worse, at least: Heron declares that the plank of the table fills 'the whole space between the boards', therefore, its width would be the distance between those boards, that is, the length of the hole-carrier, and its length, the $9 \mathrm{D}$ stated by Philon. This last dimension could be transversely accommodated without problem inside the wide frame of an inswinger. What about those 'upper frames of the table'? Philon says that they must have the width and thickness of the ladder, but he does not say: 'the width and thickness of such and such component of the ladder', consequently, I understand that Philon is meaning the dimensions of the whole ladder and the mysterious upper frames would be $17 / 10 \mathrm{D}$ wide and $1 \mathrm{D}$ thick (high) ${ }^{60}$. About their mission and number, I can only venture that they could be auxiliary elements intended to link the ladder to the table and, in such case, perhaps there were two of them. More than one reader will think that, in the end, both components - Schramm's and Marsden's 'table' and my 'upper frames'could be fairly the same thing, but I do not believe that it is legitimate to call it the 'table', for the reason above mentioned ${ }^{61}$. Finally, I agree with Marsden in equating the beams 'of length suitable for the half-springs' to those four linking both half-springs together ${ }^{62}$.

It is time now to touch Vitruvius. His chapters on artillery ${ }^{63}$ are little more than a list of components and dimensions, designed to explain the accompanying diagrams. Unfortunately for us, the diagrams are now utterly lost and the numerals for the dimensions have suffered so much during the transmission of the manuscripts that we cannot be completely sure of any of them unless it is corroborated by Philon. Paradoxically, this disaster has turned Vitruvius' text into a sort of 'land of opportunities' for many scholars who have — with the most honourable scientific intentions - created wholesale reconstructions, changing absurd - and no so absurd - readings at will to make them fit into a picture which, lacking the minimum indispensable parallels, could be little more than a pre-conceived scheme. That is the reason why I have, not only on chronological grounds, left Vitruvius for the end. On one side, current reconstructions of wooden two-armed stone-throwers rely heavily on Vitruvius and, on the other, that author is, despite its many problems, still a useful source against which the precedent paragraphs can be checked.

Vitruvius, after describing the construction of the half-spring, continues ${ }^{64}$ : 'Regulae, quae est in mensa, longitudo foraminum VIII; latitudo et crassitudo dimidium foramines. Cardines IIZ, crassitudo foraminis I99. Curvatura regulae $\Gamma C ̧$ K. Exterioris regulae latitudo et crassitudo tantundem; longitudo, quam dederit ipsa versura deformationis et parastaticae latitudo ad (et, in $\mathbf{H}^{65}$ ) suam curvaturam $K$. Superiores autem regulae aequales erunt inferioribus $K$. Mensae transversarii foraminis CCC K.' Marsden, relying heavily on Schramm and Diels' previous work ${ }^{66}$, translated the paragraph: 'The length of the beam which is connected to the table is 8 holes; the breadth and thickness, half a hole. The tenons $2 / 3,1 / 4$ of a

60 For this reason, I cannot accept Prou's proposed translation, attractive as it is, 'The cross-pieces have the same width and thickness as those of the ladder'. PROU (1877), 77. Furthermore, I have already said that ' $\varepsilon \pi i \pi \eta \gamma \mu \alpha$ ' is not a synonym of ' $\delta i \alpha ́ \pi \eta \gamma \mu \alpha$ '. Schramm -SCHRAMM (1918), 55- was of the same opinion as Prou at this respect.

61 Moreover, an intermediate element is needed between the ladder and the table (i.e. lower beams + cross-pieces + plank), otherwise, ladder and slider alone are not thick enough to 'lift' the missile to mid-stanchion level, as it is necessary for a correct functioning of any torsion machine (or not? See IRIARTE forthcoming).

62 MARSDEN (1971), 161 n. 26.

63 Vitruvius, De Arch. X, 10-12. Mainly borrowed from Agesistratus, as it seems. MARSDEN (1971), 4-5.

64 Vitruvius, De Arch. X, 11, 6. I have included the complete Latin text of the paragraph - Loeb edition by Frank Granger - mainly for comparative purposes.

65 H: Harleian 2767, British Library, London.

66 As he duly acknowledged in MARSDEN (1971), 194 n. 1. 


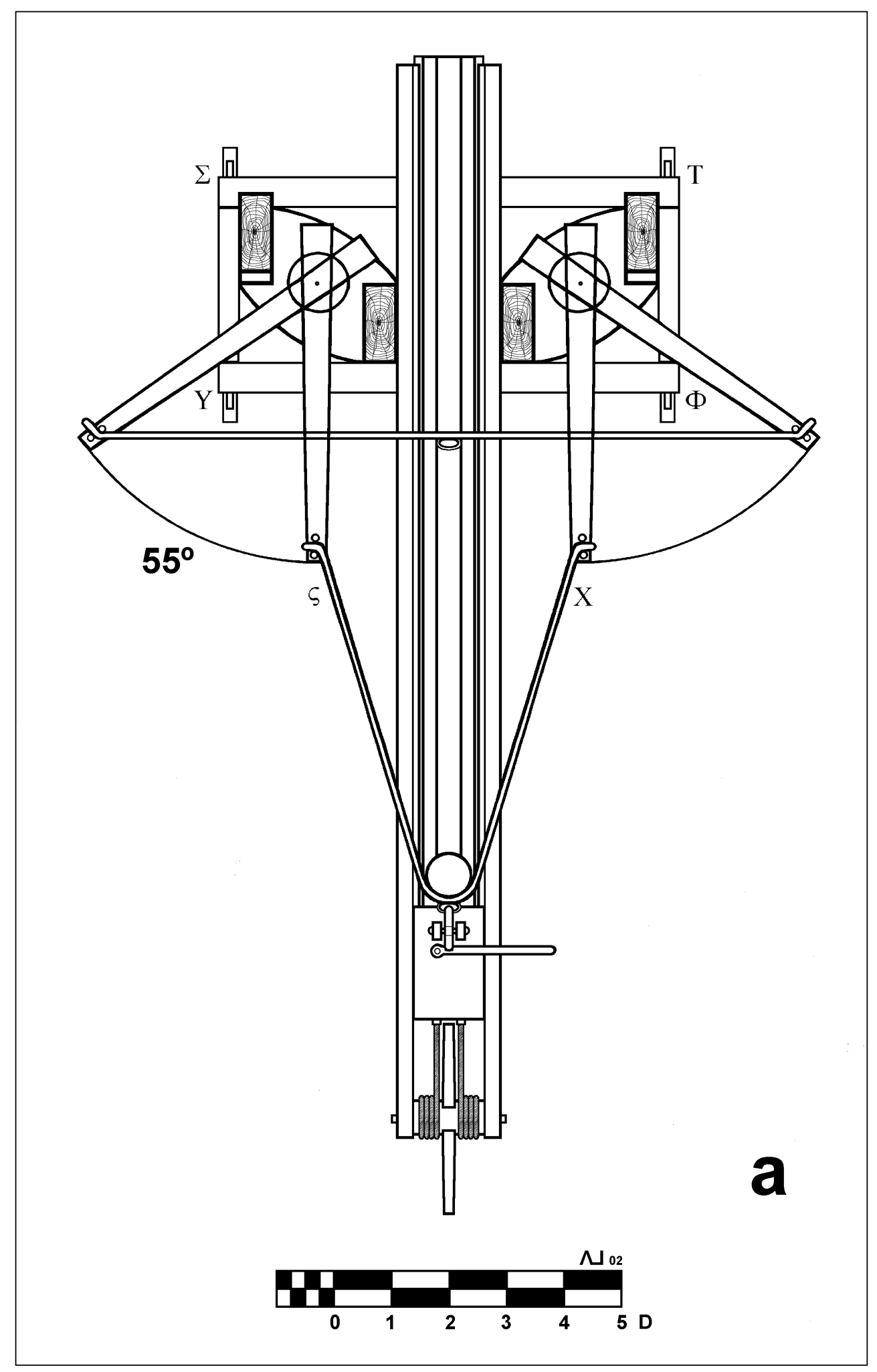

Fig. 9. a. The Greek palintonon as an outswinger. 

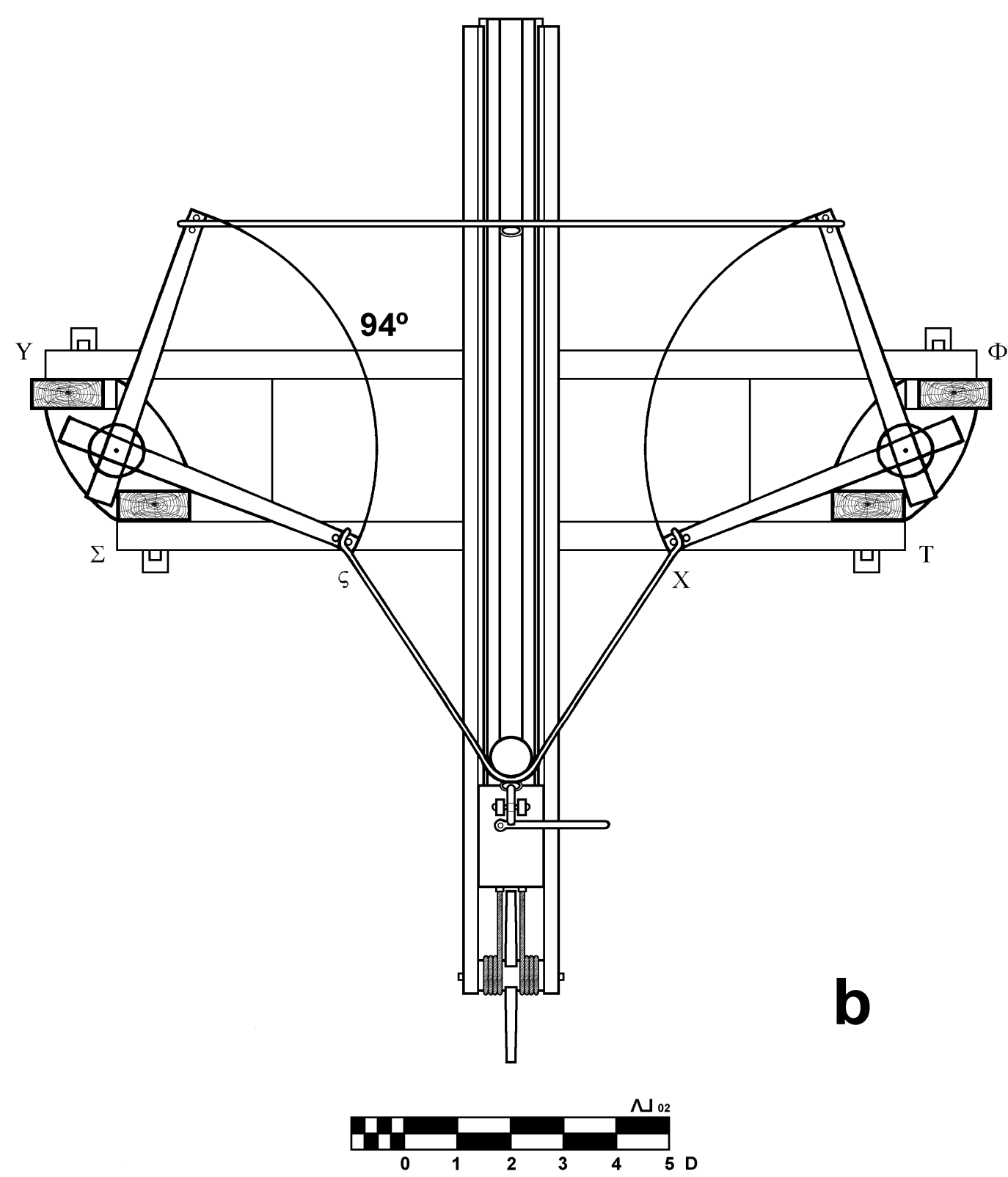

Fig. 9. b. The Greek palintonon as an inswinger.

hole in thickness. The curvature of the beam is $3 / 4$. The breadth and thickness of the outer beam are the same, its length is whatever the angle of its shape and the width of the sidestanchion add to its curvature. Now the upper beams are equal to the lower ones. The crosspieces of the table are $3 / 4$ of a hole'. 
The result ${ }^{67}$ (Fig. 10) of Marsden's work is the image everybody has still in mind today. Only fairly recently, serious doubts have been cast on the interpretation of the base ${ }^{68}$, built on Schramm's assumption that stone-throwers were indirect shooters ${ }^{69}$. Schramm's and Marsden's interpretation of the frame remains, thus, unchallenged, even if it is now plainly clear that their editions of Vitruvius' text included excessive changes, being the numerals the section most affected ${ }^{70}$. A direct conversion of the numerals in the paragraph ${ }^{71}$ concerning the frame would leave Marsden's translation as follows: 'The length of the beam which is connected to the table is 8 holes; the breadth and thickness, half a hole. The tenons, $2{ }_{16}^{7} ; 1$ $1 / 2$ of a hole in thickness. The curvature of the beam is $9 / 16$. The breadth and thickness of the outer beam are the same, its length is whatever the angle of its shape and the width of the side-stanchion add to its curvature. Now the upper beams are equal to the lower ones. The cross-pieces of the table are $3 / 4$ of a hole'.

The length of the beam 'in the table'72, identified with the rear one of the lower pair connecting both half-springs, is clearly defined in the text as VIII (8) holes. Albeit the figure could well have been in origin a VIIII ${ }^{73}$ or even a XIII, I shall not pursue that fruitless line $^{74}$. A length of 8 holes for the beam clearly points towards a narrow frame. The curvature mentioned by Vitruvius for this same beam (and for its upper counterpart, of course) has been interpreted by Schramm and Marsden as longitudinally applicable to the beam which would, therefore, embrace the curved sides of both half-springs(Fig. 10) and support their suggested way of positioning them. Unfortunately for that neat picture, the figure assigned in the text to the curvature $-9 / 16$ of a hole - is far too small for that purpose, even in case it would be the radius. Heron is the only treatise-writer who mentions a concrete radius for the curvature of the peritreta and it amounts to 3 holes $^{75}$. In my opinion, it would be fairer to acknowledge that we have not the slightest idea about what was the curvature intended for or were on the beam was it placed.

Some unspecified tenons - Vitruvius says nothing about the position and number of these cardines - are mentioned in the paragraph, cutting in two rather haphazardly the explanation of the beam 'which is in the table'. Our author does not specify whether the numeral $2 \frac{7}{16}$ holes goes for the length or for the width. The place the 'tenons' occupy in the description reminds us of those tenons mentioned by Heron, stemming from the hole-carriers and linking them to the connecting beams. If we trust the transmitted ciphers, there are insurmountable difficulties to make that connection: In case width would be meant, then the 'tenons' would span almost all the length of the hole-carrier's curved sides and they would surpass that of the straight ones. In case length would be meant, it seems excessive for a tenon. Furthermore, the 'tenons' would be $1 / 2$ hole thicker than the peritreta are. On the evi-

${ }^{67}$ MARSDEN (1971), 202, Fig. 10.

68 WILKINS (1995), 42.

69 BAATZ (1994a), 140-143.

70 See precedent footnote and WiLKINS \& MORGAN (2000), 77.

71 I have followed Marsden's -MARSDEN (1971), 187 footnote- and Wilkins' -WILKINS \& MORGAN (2000), 78lists of equivalences, both based on Schramm's work.

72 I think that 'the length of the beam, which is in the table,...' is a more straightforward translation than Marsden's 'the length of the beam, which is connected to the table,...', which, a bit unduly, emphasizes Marsden's idea of the table as a detached component not including the lower pair of connecting beams.

73 Notice the coincidence with Philon's 9 D for the table's length. PROU (1877), 254 n. 232.

74 My excuses if I sound over-pessimistic, but I find it very difficult to understand how can be Vitruvius text confidently restored when a considerable part of the information inside it — suspect of being corrupt as it is - cannot be checked against any other parallel source, except for the few dimensions in Philon's treatise. I cannot see the point in changing merrily the numerals, unless he who does it could rightly claim to know what was inside Vitruvius' and the successive copyists' minds!

${ }^{75}$ Heron, Bel. W. 95-96. Obviously, the situation remains unchanged in case we accept $3 / 4$ of a hole as the correct reading. 
dence provided by a diagram on two of the main manuscripts ${ }^{76}$ (Fig. 12), Marsden, pursuing once more Schramm's trail, interpreted them as a pair of rigidifying beams tying together each pair of connecting beams ${ }^{77}$. No matter how encouragingly near this figure of $27 / 16$ (2.44) holes could appear to be to the peritreton's width ${ }^{78}$, Vitruvius' 'tenons' cannot be equated to Heron's cross-pieces, because the same Vitruvius a little later mentions these cross-pieces of the table and assigns them a quite different thickness. Of course, the 'tenons' could always be assimilated to Philon's mysterious 'ć $\pi i \pi \eta \gamma \mu \alpha \tau \alpha$ ', but their respective thicknesses $-1 \frac{1}{2}$ and 1 - do not match very well.

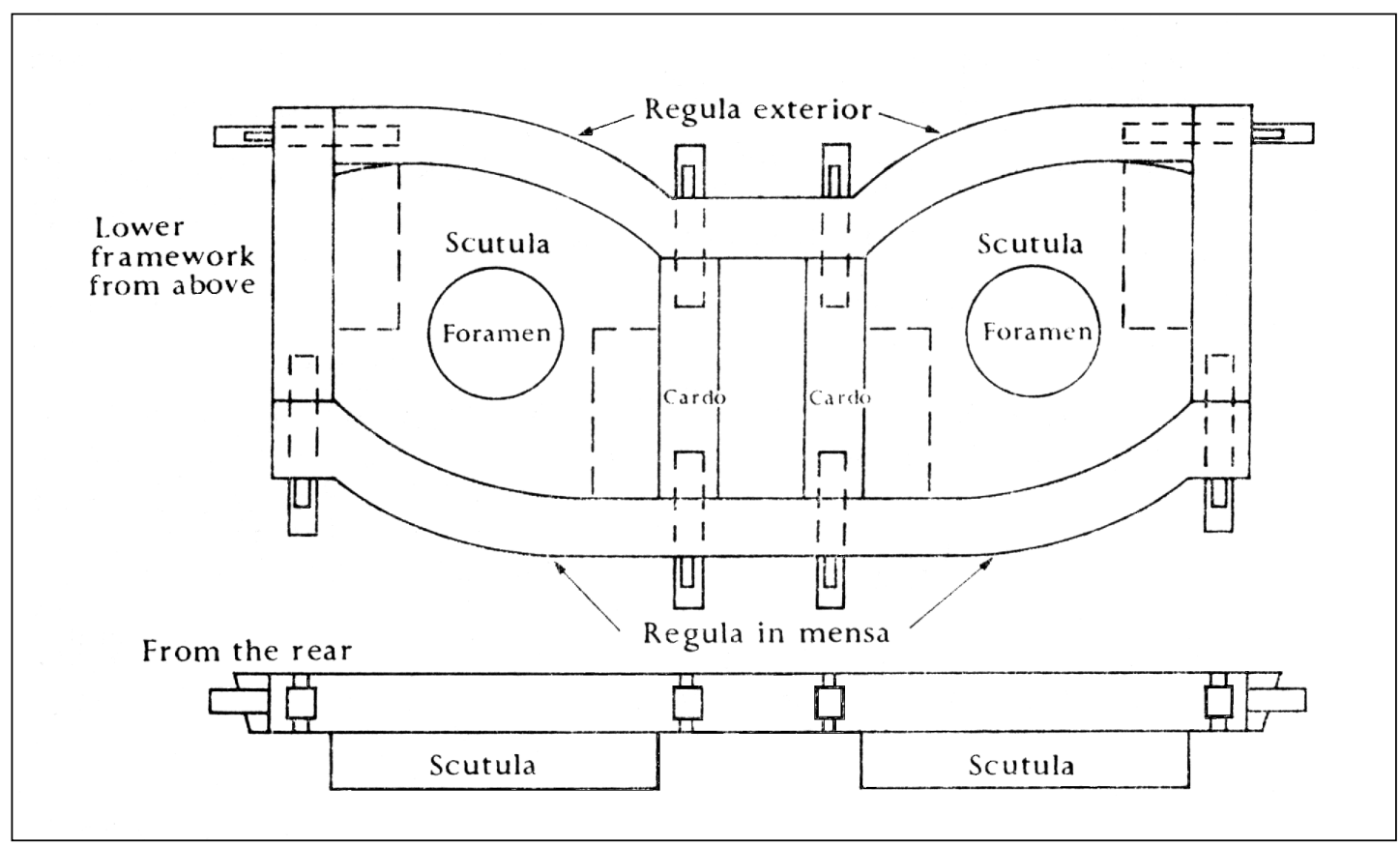

Fig. 10. The lower frame of Vitruvius' ballista (after Marsden).

Vitruvius now turns to speak of the outer beam of the pair linking both half-springs. Our Roman architect says that its width and thickness must be the same as those of its companion, that is, half a hole, but he does not give an actual figure for its length. I feel that Marsden's translation is a little forced and I would prefer to read: 'The length, what will give the angle of the design and the breadth of the side-stanchion towards its curvature.' Why a different and variable length for this beam? In case both half-springs were positioned with their straight sides parallel to each other, the respective lengths of the connecting beams would be pretty much the same. Marsden sought to explain the variation in length by using the inner beam's supposed curvature and by turning, out of a forced translation, the outer beam curved too (Fig. 10). In fact, connecting beams of different lengths would suit better an inswinging frame (Fig. $1 \& 9$ b), which actually presents two marked acute angles in its shape and which has, additionally, that angles placed where the curved bulges of the side-stanchions lye. At

\footnotetext{
76 See its discussion on next section, 'Ancient Diagrams'.

77 SChrAmm (1918), Taf. 4. MARSDEN (1971), 202 n. 31, Fig. 10.

78 Vitruvius' text says $2 \frac{1}{6}$, this time, quite distinctly stated: 'latitudo duo et sextae partis' Vitruvius, De Arch. X, 11, 4. Schramm and Diels changed it to 'duo et $S$ ', $2 \frac{1 / 2}{2}$. Philon's dimension is $2 \frac{3}{4}$. Philon, Bel. 53.
} 
any rate, it is really strange to link the length of the outer beam to the side-stanchion's width, unless they run in the same direction. In an inswinger frame, the outer beams are noticeably longer than the inner ones. Vitruvius imprecision at the hour of giving the outer beam's length maybe accounts for the existence of sundry recipes to shape the hole-carriers ${ }^{79}$, which would result in slight dimensional variations.

The last phrase related to the frame explains that 'the cross-pieces of the table are $3 / 4$ of a

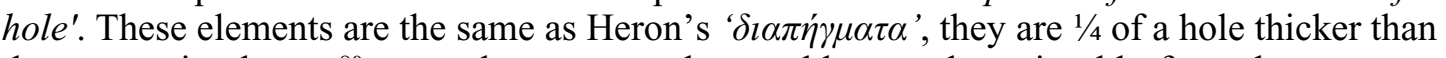
the connecting beams ${ }^{80}$ are and, consequently, would protrude noticeably from the, say, upper faces of the beams. In that case, the plank of the table would rest only on the crosspieces, with its ends maybe leaning on the lower hole-carriers.

\section{ANCIENT DIAGRAMS}

What about the ancient diagrams accompanying the treatises? The authors deemed them as important as the text itself. Unfortunately, only those belonging to Heron's Belopoeika survive, and so in Middle Byzantine copies, like the text does. If we examine the oldest extant manuscript, $\mathbf{M}^{81}$, we shall find - to our disappointment - that the diagram illustrating the palintone's definitive version, mentioned in the text, is lacking. Notwithstanding, in that manuscript, behind the end of the Belopoeika, is placed the drawing of a catapult which Wescher, quite misguidingly, linked with the description of the palintonon ${ }^{82}$. The diagram reflects hardly any of the characteristics cited in the text for the palintonon and exhibits no trace of lettering, when the rest of Belopoeika 's drawings at $\mathbf{M}$ have preserved almost intact their lettering. Therefore, there is no base to say that this diagram is a depiction of the palintonon at all. In fact, it cannot be linked to any concrete part of Heron's treatise and it really looks more like a big arrow-shooter, possessing a forked claw, while a big dart is placed on its slider's channel ${ }^{83}$ (Fig. 11).

79 The surviving treatises transmit four methods — one Heron, two Philon and one Vitruvius —, all of them different.

80 And ${ }^{11} / 36$ (0.31) of a hole thicker than Philon's connecting beams.

${ }^{81}$ For the different manuscripts preserving the ancient artillery treatises and their mutual relationship, see WESCHER (1867), IX-XLIV and MARSDEN (1971), 8-15. Probably, several manuscripts -written in Greek uncial majuscule letters- reached a Byzantine scriptorium around the tenth century A.D. There, it had been decided to make a compilation of scientific treatises, especially those on poliorcetics. A reader dictated the text to several scribes at a time, in order to increase production of copies. One of those copies — written already in Greek cursive - has survived until our times, included in a wider manuscript known, after Wescher, as M: Codex Parisinus inter supplementa Graeca 607; Bibliothèque Nationale, Paris.

One of the copies made in parallel to $\mathbf{M}$ and now lost $-\mathbf{y}$ - was transferred to another Byzantine scriptorium, where a new and more ambitious compilation $-\mathbf{z}-$ was being prepared, maybe during the eleventh century A.D. We can have a faint idea about how diagrams in $\mathbf{y}$ looked like through a careless partial copy of it which was made in the sixteenth century A.D., F: Fragmenta Vindobonensia 120, olim 113; Österreichische NationalBibliothek, Vienna. F's figures, roughly traced and without lettering as they are, resemble very closely those of $\mathbf{M}$.

From the several copies made of $\mathbf{z}$-still during the eleventh century- two almost identical ones still survive in good condition, P: Codex Parisinus Gr. 2442; Bibliothèque Nationale, Paris. and V: Codex Vaticanus Gr. 1164; Biblioteca Vaticana, Rome.

82 WeSCHER (1867), 103, fig. XXXII. The diagram, in fol. 55v, is in fact placed between the Belopoeika and the Cheiroballistra, the former's explicit being at the bottom of fol. 55 and the latter's incipit, at the top of fol. 56. Even if it is easy to see that the catapult represented has nothing to do with the Cheiroballistra, it is more difficult to ascertain its real connection, if any, with the Belopoeika.

83 The frame is quite indistinct and there is no indication of washers on it. Spring-cords, arms, case, slider and trigger mechanism are very clearly depicted. Perhaps the most interesting feature on this diagram is the pull-back mechanism: Several cords in two groups stem from the enlarged slider's back section and it looks like if a double pulleysystem was used but, unfortunately, its precise details cannot be traced; a wide drum with holes for handspikes is con- 


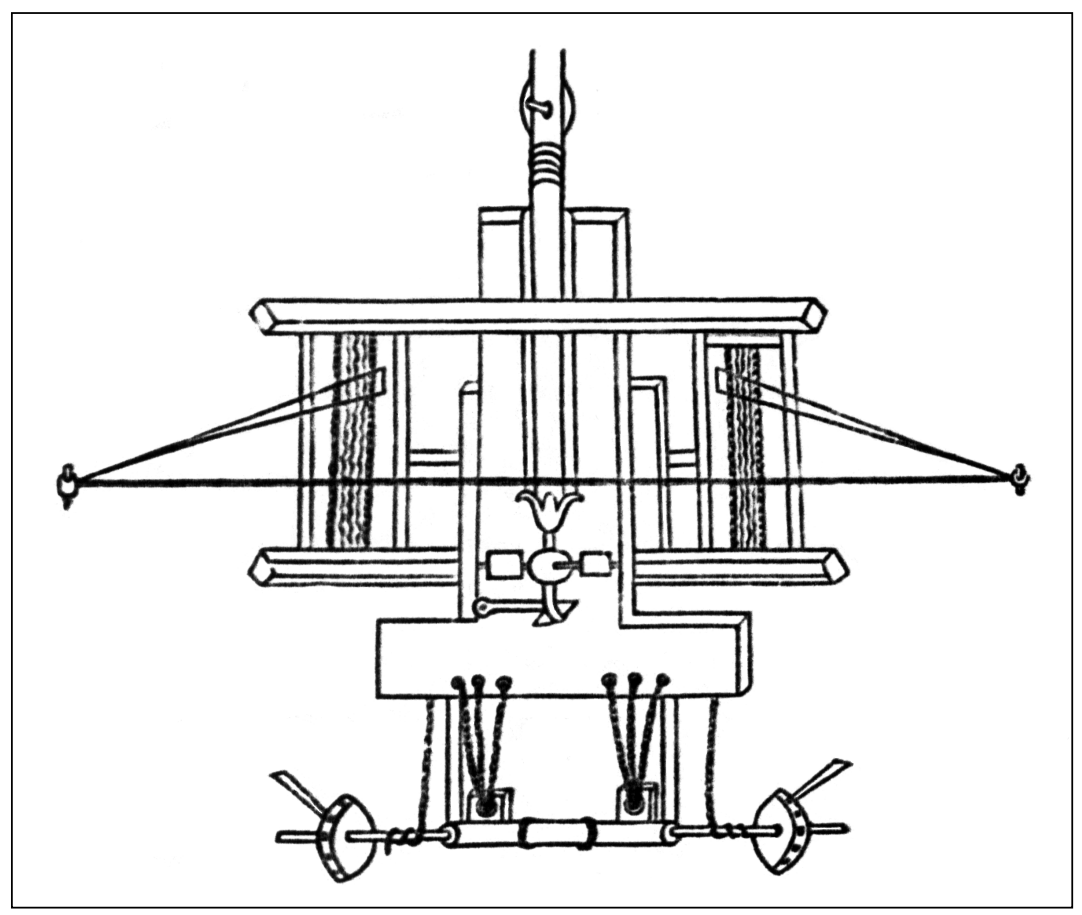

Fig. 11. The final diagram of Heron's Belopoeika (after Wescher).

The diagrams depicting the palintonon in $\mathbf{P}$ and $\mathbf{V}$ are illusionistically rendered in some sort of axonometric perspective (Fig. 12). They have been used from Schramm on as the basis for reconstructing the ill-defined frame system of horizontal beams that connected both halfsprings in palintones. The man or team responsible for the $\mathbf{z}$ compilation - from which $\mathbf{P}$ and $\mathbf{V}$ were copied - maybe perceived the lack of the palintonon diagram in the archetype $\mathbf{y}$, which was almost identical to $\mathbf{M}$, and decided to elaborate a new one; he did equally re-draw the first and last diagrams in the Cheiroballistra and some others. We can guess that, lacking any reliable model, he reconstructed it only out of the description given in the text. Anyway, even if our compiler had evidently some acquaintance with torsion artillery, as his re-drawn diagrams show, we cannot have the slightest idea about his degree of knowledge regarding the old woodenframed artillery or if he had some other paradigm on hand to help him in his task ${ }^{84}$.

The figures representing Heron's palintone in $\mathbf{P}$ and $\mathbf{V}$ are not, thus, very trustworthy. Moreover, they exhibit clear inconsistencies: If the machine is a stone-thrower, why has a big arrow been placed on the slider's channel? If side- and counter-stanchions are perpendicularly set to the frame, as they seem to be, why do their paired tenons appear on the sides of the hole-carriers which are parallel to it?

nected to each side of the revolving axle, only one handspike is inserted in both drums, the other apparent ones being the tips of the axle.

${ }^{84}$ Maybe his carelessness surpassed his acquaintance with the subject, after all. On $\mathbf{M}$, fol. $52 \mathrm{v}$, the frame of the euthytonon is portrayed without stand, case or slider, but two ladder-like features, the lowest one labeled:'

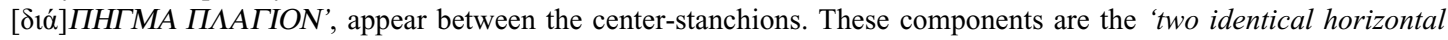
cross-pieces running across their whole width (of the center-stanchions)' (Bel. W. 105-104) to link case and frame together. Well, on $\mathbf{P}$ fol. 77, the same euthytonon diagram has lost its lettering, partially substituted by labels, and our draughtsman has supplied the frame with stock and windlass, but the slider is running inside a ladder much like that in the palintone diagram! He surely mistook the 'horizontal cross-pieces' for a disassembled ladder. Copies of both diagrams, in WESCHER (1867), 106, fig. XXXIII and XXXIV. 


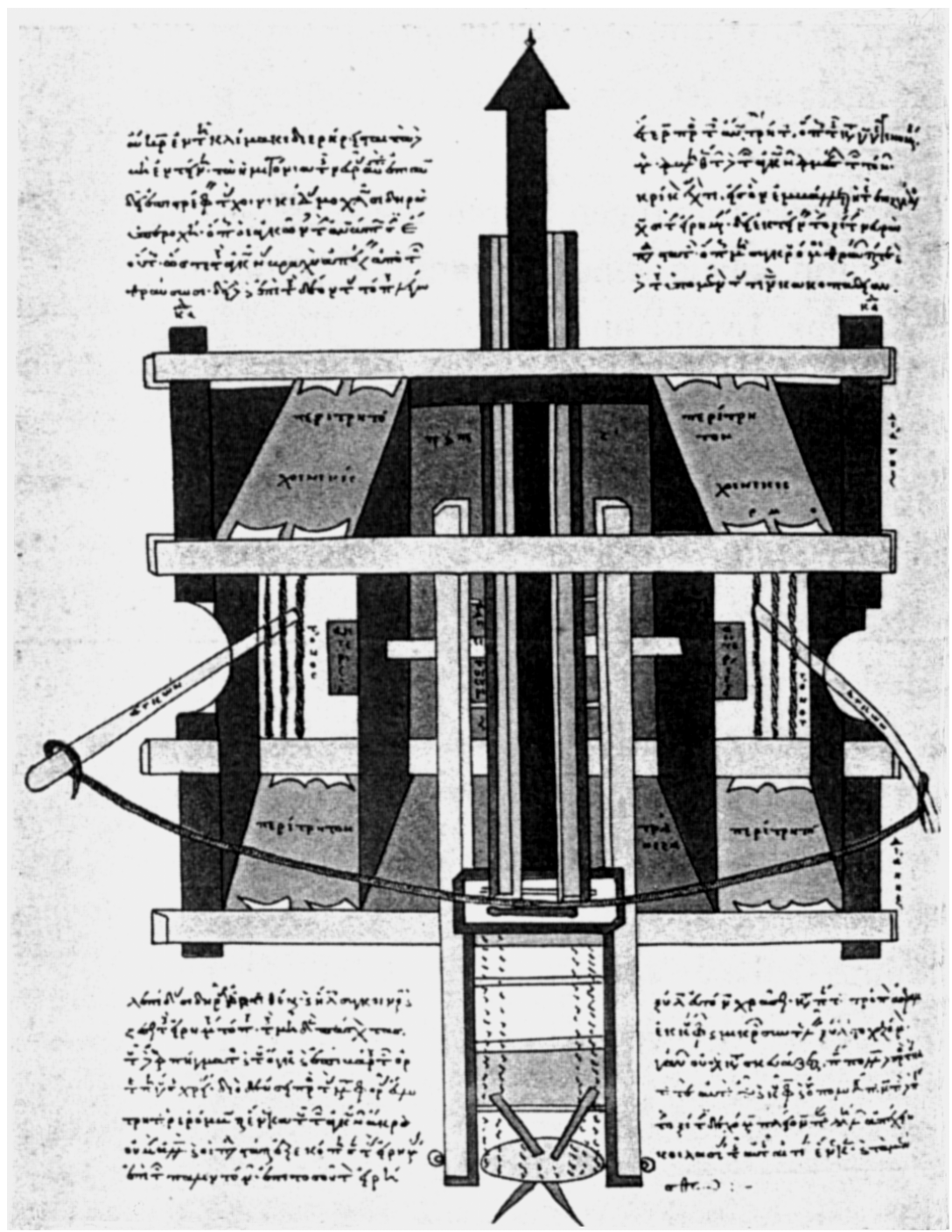

Fig. 12. The diagram of the palintonon on codex $\mathbf{P}$ of Heron's Belopoeika (after Schramm).

With regard to this last feature, one more piece of evidence, slight as it is, must be brought forward: The diagram depicting the hole-carrier in $\mathbf{M}$ is placed having its straight sides - those with the holes intended for the stanchions' paired tenons - horizontally set ${ }^{85}$, and some kind of intentionality could be laying behind this choice - i.e. the conscious or unconscious tendency to represent a component always in the same position than it will have on the assembled diagram - as, for example, that which Marsden's re-tracing of the same diagram ${ }^{86}$ — turned $90^{\circ}$ - allows to ascertain. Once more, this positioning of the peritreton on the ancient diagram would point to inswinging, but without enough rotundity ${ }^{87}$.

85 Fol. 50v. Reproduced in WeSCHER (1867), 95, fig. XXIX.

86 MARSDEN (1971), 52, Fig. 15.

87 One never knows to which extent these diagrams are trustworthy. Combining the lettering of the hole-carrier diagram in fol. $50 \mathrm{v}$ with that of the side-stanchion in fol. 50 and with that of the counter-stanchion described in the text, we can arrive to the conclusion that -in fol. $50 \mathrm{v}$ figure- we are dealing with the upper peritreton. Notwithstanding, 
Surprisingly, another short treatise with diagrams - generally taken as almost useless to artillery - can throw some light on this vexed question of how the arms worked, at least in the metallic-framed palintones: the fourth century A.D. 'De Rebus Bellicis'. Two arrowthrowing catapults are described in it, the so-called 'ballista quadrirotis' and 'ballista fulminalis'. The texts describing both weapons are short and so imprecise that they cast more doubts than they solve ${ }^{88}$. Anyway, the anonymous author seems to lay much emphasis on the accompanying illustrations, which have survived but, unfortunately, in a highly corrupt condition. In this case we can take for granted that the medieval draughtsman did not understand at all what he was copying; whether it was the Ottonian copyist's fault or his Carolingian predecessor's or even if the Late Roman archetype(s) depicted absurd machines, we shall never know ${ }^{89}$. I think that Marsden was totally right when he said that it can be scarcely doubt that both ballistae were powered by torsion springs ${ }^{90}$ and that, moreover, enough traces of the system can be still detected on the miniatures, in spite of copyists' ignorance and deteriorated originals.

On the 'ballista fulminalis', a cylinder is vertically placed near the front of the box-like structure, inserted between two long quadrangular horizontal beams. It is inconsistently depicted as smooth-surfaced or as crisscrossed. Hassall tried to view a screw on the cylinder, but the hatching reminds more of twisted ropes than of screw threads ${ }^{91}$ (Fig. 13). I think that the cylinder is nothing but a disfigured torsion spring ${ }^{92}$ which, to make things even clearer, has a stick inserted in the middle of its length - where the bow-arm uses to be - and a pill-box-like feature placed on its vertical, below the lower beam, maybe the last remainder of a washer.

On the 'ballista quadrirotis', we find the same cylinder on the same position, this time without any hatching on its surface. It is remarkable that the 'arm' seems to have its longer portion pointing towards the inner part of the structure's front face and that a second 'arm' appears occasionally, symmetrically set with respect to the former one (Fig. 14).

We can confidently conclude that both machines were originally equipped with a pair of conventional torsion springs. As it is the norm in Late Empire, the springs were short and, if proportions have been minimally kept on the miniatures, they were set quite apart one from the other, that is, the frames were low and wide. Why have the copyists detached arms and springs from the 'arch' and bowstring? Unless their archetypes were hopelessly deteriorated, the only explanation left is that they did not understand at all what they were reproducing. Even if we assume that they had not the slightest idea on torsion springs, metallic frames, case, slider, trigger mechanism or pulley systems, surely bows and crossbows were not totally alien to them. Therefore, if the copyists subverted something as obvious as the relation arm-bowstring, we could rightly suppose that either they did not see any arms at all on their models or that they were unable to recognize them as such. I am inclined to choose the sec-

relying on the relative positions of holes and tenons, designed, in that order, with the letters $\Xi$ and $O$, we could also arrive to the conclusion that the bulge on the side-stanchion pointed towards the diamond's obtuse angle instead of towards the acute one (It is possible to check it on MARSDEN (1971), 52, Fig. 13 and 15), as everybody understands it. That configuration would give a strange inswinger and an impossible outswinger, but it would mainly run counter Heron's statement (Bel. W. 102-104): 'The hole-carriers are rhomboidal so that the end of the arms holding the bowstring may be further apart'. The phrase is equally valid for an inswinger as well as for an outswinger, but only if the bulges protrude outwards or forwards, respectively.

88 MARSDEN (1971), 240-246; HASSAll (1979), 80-84; Giardina (1989), 74-78, 99-101.

89 There are only two illustrated manuscripts. The miniatures on C-Oxoniensis Canonicianus class. lat. Misc. 378; Bodleian Library, Oxford- coincide, except in minor details, with the two series of miniatures on $\mathbf{M}-$ Monacensis Latinus 10291; Bayerische Staatsbibliothek, Munich-; we can conclude, therefore, that they follow quite faithfully those on the practically lost Codex Spirensis, of Ottonian date, from which both were copied. GIARDINA (1989), LIII-LV.

90 MARSDEN (1971), 234-235.

91 HASSALl (1979), 80. I have used here the woodcuts on Gelenius' editio princeps of 1552 because they are -in more than one sense- easier to reproduce.

92 No need to remember that, on Trajan's Column, the springs are also rendered as cylinders. 
ond possibility and I would dare to say that inswinging arms would be the kind of arms that could completely puzzle our men. This theory would find an acceptable support in the 'inswinging' residual arms featured on some depictions of the 'ballista quadrirotis' (Fig. 14).
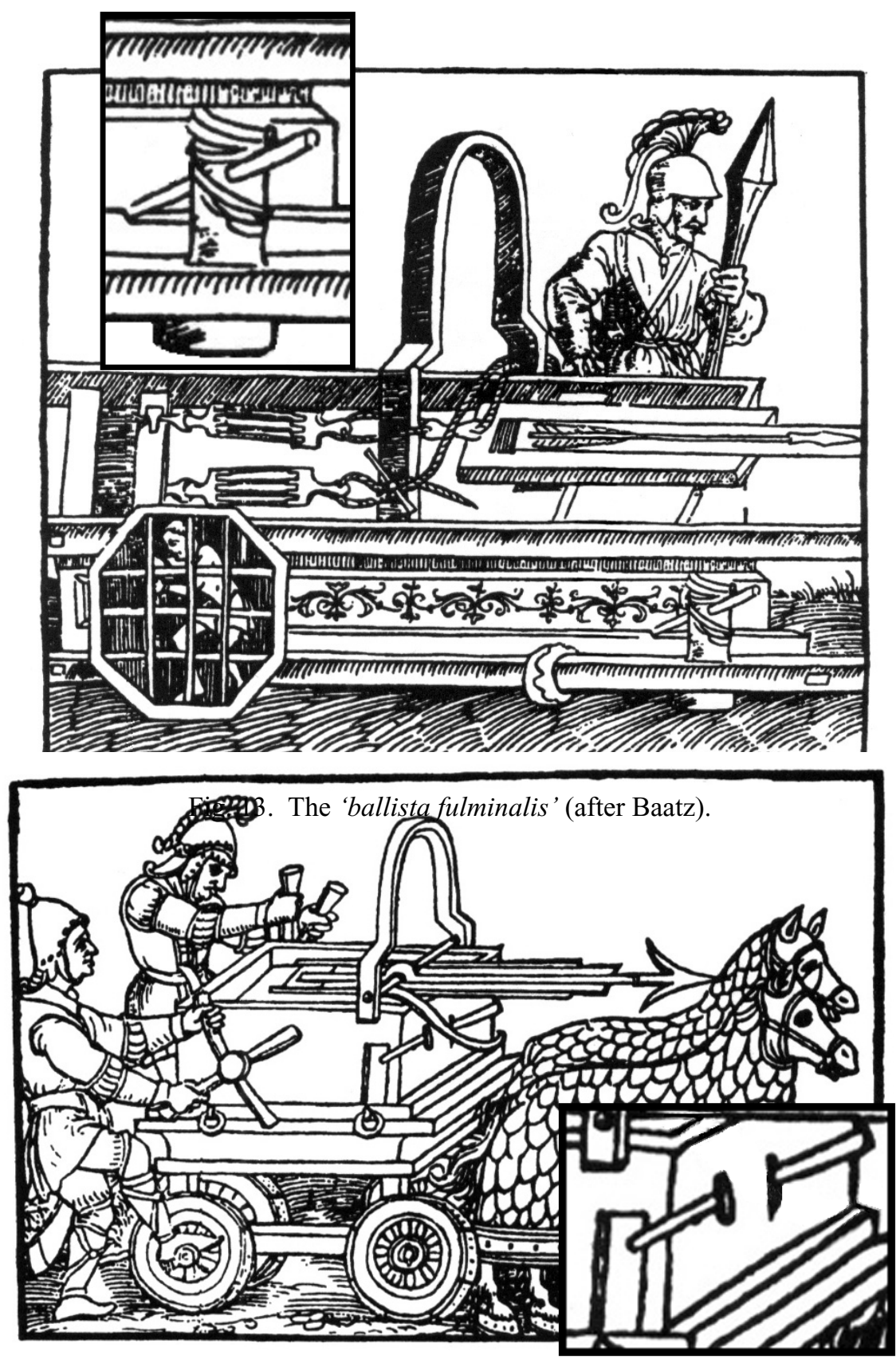

Fig. 14. The 'ballista quadrirotis' (after Baatz). 


\section{A BIT OF ETHIMOLOGY}

Even if ethimology is by no means the firmest ground to try to settle anything, I think that this survey would be uncomplete if I would not refer to the meaning lying behind the words 'euthytonon' and 'palintonon'. Through the years of investigation, this question has been perceived as quite relevant by the successive scholars ${ }^{93}$. Köchly and Rüstow ${ }^{94}$ translated 'straightsprings' and 'angled-springs', but they interpreted that, in palintones, the arms were inserted angled in the vertical plane, which reverted in an inefficient use of the energy stored by the springs. Prou ${ }^{95}$ did not directly translate both terms, but equated them with ancient hand-bows of simple (euthytone) and double curvature (palintone), he concluded that in euthytone engines and bows, the arms formed an almost straight line when they were at rest, while in palintone engines, the arms in the resting position were directed forwards, like the ears of the unstrung palintone bows. Schramm ${ }^{96}$ also related both kinds of machines with the hand-bows, but just to finish translating something like 'direct shooter' and 'indirect shooter'. Marsden ${ }^{97}$, even if retaining the concept of indirect shooting by palintones, translated their name as 'V-springs' and 'straight-springs' for euthytones; like his predecessors, he seeked to equate the homonym machines and hand-bows, with an appealing outlined drawing of a strung double-curvature bow over a palintone frame ${ }^{98}$. In my opinion, 'straight-springs' is a fair translation for 'euthytonon'; thus, Schramm's 'direct shooter', if still may have something to do with the Greek word's meaning, is not very exact. On the other side, 'indirect-shooter' for 'palintonon' is sheer invention, while 'angled-springs' or 'V-springs' seem just barely adequate. I think that 'backwards-springs' or 'springs bending back' ${ }^{99}$ stick closer to the meaning, but 'pálin' also means 'reverse' and, therefore, 'reverse-springs' is possible too. This last acceptation would hint at the idea that, in palintones, the springs were placed or functioned the opposite way than in euthytones ${ }^{100}$.

\section{CONCLUSIONS}

With the information currently available, it is not possible to affirm categorically whether all - and I am meaning all of them - palintones were either outswingers or inswingers. All the tentative reconstructions of palintones — 'orthodox' or 'unorthodox'hitherto made are, at their best, nothing but educated guesses, based on defective and often ambiguous sources, without a bit of solid evidence to contrast them.

In any case, the only attested preserved part of a true ballista, the Hatra frame plating ${ }^{101}$, seems to be designed for an inswinging configuration of its arms. An accurate working reconstruction of this machine is highly desirable, not only to test its full potential as an inswinger but to try what it could really achieve in an outswinging configuration, as well ${ }^{102}$.

93 Nevertheless, only Heron uses consistently both words, from his preface 'Of the engines mentioned, some are euthytones, others are named palintones' (Bel. W. 74) on.

94 SCHRAMM (1918), 13-15.

95 Prou (1877), 79-84.

96 SCHRAMM (1918), 14, n. 1.

97 MARSDEN (1969), 22-23; 1971, 44-45, n. 5.

98 MARSDEN (1969), 22, Fig. 12.

99 Marsden pointed out this last variant when speaking on the composite bow. MARSDEN (1969), 10.

100 In 1867, P. Mérimée wrote that 'The palintone catapult is so called because it has its bow-arms inserted the opposite way than the other machines, just like the palintone hand-bow, when at rest, has its tips pointing towards the opposite direction to the tension'. PROU (1877), 80.

101 Quite atypical, as it is.

102 In my opinion, the real success of an experiment goes more with communicating honestly the true results than with demonstrating one self's own point. Somebody has, unfortunately, to investigate the paths that lead to dead-ends too and, the sooner and better failures are published, the less probably will they be repeated. 
It is evident that several full-scale working replicas, constructed along last century, have proved that big wooden outswinger palintones are efficient and successful machines. Now the time has come to try the same with the inswinger palintones and build one of comparable size to the others ${ }^{103}$. Anyway, experiments with metallic-framed inswinger arrow-shooting ballistae have clearly confirmed that they are more efficient than their outswinger peers ${ }^{104}$.

As I have said earlier, we have not enough information yet as to tell if Greek and Roman artillerymen employed either inswinger or outswinger — or both — palintones but, reminding what Heron and Philon wrote - 'The object of artillery-construction is the projection of a missile over long range, at a given target, to strike with powerful impact; to this end must all one's attention be directed'105 'We must direct most of our research, as we have often insisted, to achieving long range and to tracking down the features of engines which lead to power.'106 — I cannot help the impression that they would have preferred inswingers to outswingers. The answer to our questions may come in a future, if enough remains of palintones come to light; the sheer importance of such discovery will, hopefully, quickly throw aside minor matters on 'who is right' and 'who is wrong' in favour of the only essential thing, i.e., 'what is true'.

In the meantime, maybe those scholars, who are so aware of 'Heron's authoritative comments on torsion machines' or 'the defined purpose of catapult construction' and 'the ballistic requirement of Roman armies', should better start looking around...

AITOR IRIARTE

Altube, 4, 4 E.E-48002, Bilbao (Spain).E-mail: bonnefoy@euskalnet.net

\section{BIBLIOGRAPHY}

AnsteE, J. (1998): “«Tours de Force». An experimental Catapult / Ballista' Studia Danubiana. Symposia I, 131-139.

BAATZ, D. (1978): 'Recent Finds of Ancient Artillery' Britannia 9, 1-17.

BAATZ, D.\& FeugÈRE, M. (1981): 'Eléments d'une catapulte romaine trouvée à Lyon' Gallia 39, 201-209.

BAATZ, D. (1988): ‘Eine Katapult-Spannbuchse aus Pityus, Georgien’ Saalburg-Jahrbuch 44, 59-64.

BAATZ, D. (1994a): 'Waffenwirkung antiker Katapulte', Bauten und Katapulte des römischen Heeres. Mavors Roman Army Researches 11, 136-145.

BAATZ, D. (1994b): 'Katapultfunde 1914-1988', Bauten und Katapulte des römischen Heeres. Mavors Roman Army Researches 11, 275-283.

BAATZ, D. (1999): 'Katapulte und mechanische Handwaffen des spätrömichen Heeres'. Journal of Roman Military Equipment Studies 10, 5-19.

BARKER, J. (1999): 'Ancient Arrow-Shooting Machines'. Journal of the Society of ArcherAntiquaries 44, 16-21.

${ }^{103}$ I am fully aware of the great deal of hard work and money involved in such operation, but it is the only real touchstone to check a machine's functionality. Everything seems to perform well on paper, if adequately and nicely drawn; not so many devices work as a scale model; only the really viable ones resist full-scale.

${ }^{104}$ As far as I have been able to test it by myself, my cheiroballistra and the second reconstruction of the Orşova remains as a carroballista by the late John Anstee.

105 Heron, Bel. W. 74.

106 Philon, Bel. 76. In Bel. 51, Philon says the same than Heron almost exactly. 
BISHOP, M.C. \& COULSTON, J.C.N. (1993): Roman military equipment from the Punic Wars to the fall of Rome, (London).

Boube-Piccot, C. (1988): 'Eléments de catapultes en bronze découverts en Maurétanie Tingitane' Bulletin d'archéologie marocaine XVII, 209-230.

Boube-Piccot, C. (1994): Les bronces antiques du Maroc: IV. L'équipement militaire et l'armement, (Paris).

GiARDinA, A. (1989): Le cose della guerra, (Verona).

GudEA, N. \& BAATZ, D. (1974): 'Teile spätrömische Ballisten aus Gornea und Orşova (Rumänien)' Saalburg-Jahrbuch 31, 50-72.

HARPHAM, R. \& STEVEnSON, D.W.W. (1997): 'Heron's Cheiroballistra (A Roman Torsion Crossbow) Journal of the Society of Archer-Antiquaries 40, 13-17.

Hassall, M. (1979): 'The inventions'. De Rebus Bellicis. Part I. Aspects of the Rebus Bellicis. B.A.R. International Series LXIII, 77-95.

HASSALL, M. (1999): 'Perspectives on Greek and Roman catapults' Archaeology International 1998/1999, 23-26.

IRIARTE, A. (2000): 'Pseudo-Heron's cheiroballistra a(nother) reconstruction: I. Theoretics', Journal of Roman Military Equipment Studies 11, 47-75.

IRIARTE, A. (forthcoming): 'More about the Teruel catapult', Journal of Roman Military Equipment Studies 12.

MARSDEN, E.W. (1969): Greek and Roman Artillery. Historical Development, (Oxford).

Marsden, E.W. (1971): Greek and Roman Artillery. Technical Treatises, (Oxford).

Prou, V. (1877): 'La Chirobaliste d'Héron d'Alexandrie' Notices et Extraits des manuscrits de la Bibliothèque nationale et autres bibliothèques 26.2, 1-319, (Paris).

SCHRAMm, E. (1918): Die antiken Geschütze der Saalburg, (Reprint, Bad Homburg 1980).

Soedel, W. \& Foley, V. (1979): 'Ancient Catapults' Scientific American Vol. 240 nº 3 March 1979, 120-129.

WesCher, C. (1867): Poliorcètique des Grecs, (Paris).

WILKINS, A. (1995): 'Reconstructing the cheiroballistra', Journal of Roman Military Equipment Studies 6, 5-59.

Wilkins, A. \& MoRgan, L. (2000): 'Scorpio and cheiroballistra', Journal of Roman Military Equipment Studies 11, 77-101. 